\title{
Phase formation, crystal structures and magnetic properties of perovskite-type phases in the system $\mathrm{La}_{2} \mathrm{Co}_{1+z}\left(\mathrm{Mg}_{\mathrm{x}} \mathrm{Ti}_{1-\mathrm{x}}\right)_{1-\mathrm{z}} \mathrm{O}_{6}$.
}

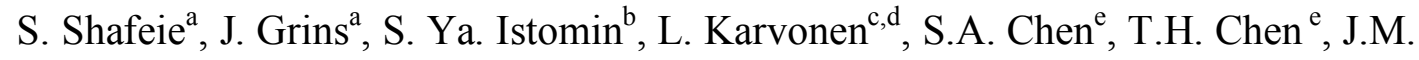

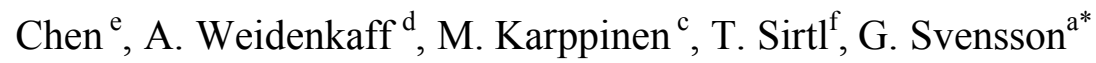

${ }^{\mathrm{a} D e p a r t m e n t ~ o f ~ M a t e r i a l s ~ a n d ~ E n v i r o n m e n t a l ~ C h e m i s t r y, ~ S t o c k h o l m ~ U n i v e r s i t y, ~ S E ~-~}$ 10691, Stockholm, Sweden

${ }^{\mathrm{b}}$ Department of Chemistry, Moscow state University, 11992, Moscow, Russia

${ }^{c}$ Laboratory of Inorganic Chemistry, Aalto University School of Science and Technology, FI - 00076, Aalto, Finland

${ }^{\mathrm{d}}$ Laboratory for Solid State Chemistry and Catalysis, EMPA-Swiss Federal Laboratories for Materials Science and Technology, $\mathrm{CH}-8600$, Dübendorf, Switzerland

${ }^{\mathrm{e}}$ National Synchrotron Radiation Research Center, Hsinchu 30076, Taiwan, ROC

${ }^{\mathrm{f}}$ Department of Physics, Freie Universitet, 14195, Berlin, Germany

*Corresponding author:

Gunnar Svensson

Department of Materials and Environmental Chemistry, Stockholm University, SE 10691, Stockholm, Sweden

E-mail: gunnar.svensson@mmk.su.se

Telephone: +468161254

Fax +468152187 


\section{Abstract}

Perovskite-type cobaltates in the system $\mathrm{La}_{2} \mathrm{Co}_{1+\mathrm{z}}\left(\mathrm{Mg}_{\mathrm{x}} \mathrm{Ti}_{1-\mathrm{x}}\right)_{1-\mathrm{z}} \mathrm{O}_{6}$ were studied for $\mathrm{z}=$ $0 \leq \mathrm{x} \leq 0.6$ and $0 \leq \mathrm{x}<0.9$, using $\mathrm{X}$-ray and neutron powder diffraction, electron diffraction (ED), magnetic susceptibility measurements and X-ray absorption nearedge structure (XANES) spectroscopy. The samples were synthesised using the citrate route in air at $1350^{\circ} \mathrm{C}$. The space group symmetry of the structure changes from $P 2_{1} / n$ via Pbnm to $R \overline{3} c$ with both increasing $\mathrm{Mg}$ content and increasing Co content. The $\mathrm{La}_{2} \mathrm{Co}\left(\mathrm{Mg}_{\mathrm{x}} \mathrm{Ti}_{1-\mathrm{x}}\right) \mathrm{O}_{6}(\mathrm{z}=0)$ compounds show anti-ferromagnetic couplings of the magnetic moments for the Co below $15 \mathrm{~K}$ for $\mathrm{x}=0,0.1$ and 0.2 . XANES spectra show for the compositions $0 \leq \mathrm{x} \leq 0.5$ a linear decrease in the $L_{3} /\left(L_{3}+L_{2}\right)$ Co- $L_{2,3}$ edge branching ratio with $\mathrm{x}$, in agreement with a decrease of the average Co ion spin state, from a high-spin to a lower-spin state, with decreasing nominal $\mathrm{Co}^{2+}$ ion content.

\section{Keywords}

Cobaltates, perovskite, $\mathrm{X}$-ray diffraction, neutron diffraction, magnetic susceptibility, electron diffraction, XANES 


\section{Introduction}

Compounds with crystal structures related to the cubic $\mathrm{ABX}_{3}$ perovskite structure are among the most compositionally flexible ones and can incorporate the majority of the metallic elements in the periodic table [1]. Several authors have discussed the structural distortions that lead to other space group symmetries than the ideal $\operatorname{Pm} \overline{3} m$ $[2,3,4]$. A simple quantification of the mismatch of the sizes of the A, B and X atoms that promotes distortions is given by the Goldschmidt tolerance factor $t=\left(r_{A}+r_{X}\right) / \sqrt{2}\left(r_{B}+r_{X}\right)$ [5], with $\mathrm{r}_{\mathrm{A}}, \mathrm{r}_{\mathrm{B}}$ and $\mathrm{r}_{\mathrm{X}}$ representing the ionic radii of the $\mathrm{A}$, $\mathrm{B}$ and $\mathrm{X}$ ions respectively. Distortions occur when $t$ deviates significantly from 1 (normally $t<1$ ).

Perovskite-type compounds containing cobalt have attracted considerable interest, as they exhibit e.g. magnetic, thermoelectric and catalytic properties, ionic and electronic conductivity and magneto-resistivity that may be utilized in different applications $[6,7,8,9,10,11]$. The high compositional flexibility of the perovskite-type structures allows for varied ways to control and optimize these properties.

The perovskite-type cobaltate $\mathrm{LaCoO}_{3-\delta}$ has been extensively studied during the last two decades due to its intricate electronic structure and catalytic and electronic transport properties. The tolerance factor is 1.02 , but despite this the $\mathrm{CoO}_{6}$ octahedra are tilted to maximize the La-O bond strength, and the structure therefore becomes rhombohedral with $R \overline{3} c$ symmetry. As is generally known for transition metal oxides of perovskite related structures they may be prepared oxygen deficient and thereby converted into oxygen ion conductors $[12,13,14]$. The electron conduction in $\mathrm{LaCoO}_{3}$, and related materials, has been described as electron or hole hopping between cobalt atoms with different oxidation states via Co-O-Co links $[8,15]$. The evaluation of the electronic structure is complicated by the temperature sensitivity of the $\mathrm{Co}^{3+}$ spin state: while the low-spin (LS) configuration $\left(t_{2 g}^{6} e_{g}^{0}\right)$ prevails at low-temperatures, transition to higher spin state takes place already above $85 \mathrm{~K}$. Whether an intermediate-spin (IS) state $\left(t_{2 g}^{5} e_{g}^{1}\right)$ is populated before the highspin (HS) state $\left(t_{2 g}^{4} e_{g}^{2}\right)$ is subject under ongoing debate $[16,17,18]$. The sensitivity is a consequence of similar magnitudes of the exchange energy for the pairing of electrons ( $J$ coupling) and of the crystal-field splitting, leading to a small energy difference $(\leq 0.08 \mathrm{eV})[19]$ between the low- and high-spin configurations. 
A potential use of materials related to $\mathrm{LaCoO}_{3}$ is in solid oxide fuel cells (SOFCs). For these, mismatch in thermal expansion between components is a major problem that causes degradation and decrease in the lifetime of the cells [20]. Several cobaltates with adequate conductivity and catalytic properties have been found unsuitable due to their thermal expansion coefficients [21]. The thermal expansion coefficients are among others strongly influenced by the temperature dependent changes of the $\mathrm{Co}^{3+}$ spin-state also having an effect on the ionic radius, viz. $\operatorname{LS}(0.52 \AA)<\operatorname{IS}(0.56 \AA)<\operatorname{HS}(0.61 \AA)$ [22,23]. A good understanding of the electronic structures is thus important in order to achieve suitable thermal expansion coefficients and electrical and magnetic properties [16,17,21,24].

The wish to control the electronic structure of $\mathrm{LaCoO}_{3}$ has brought about numerous investigations on alio- and iso-valent substitutions of the A and B cations. A well-studied example of substitution at the A-site position is $\mathrm{La}_{1-\mathrm{x}} \mathrm{Sr}_{\mathrm{x}} \mathrm{CoO}_{3}$ $[24,25,26,27]$. However, the replacement of $\mathrm{La}^{3+}$ by $^{2+}$ does not lead to an oxidation of the $\mathrm{Co}^{3+}$ but to a formation of oxygen vacancies and oxidation of $\mathrm{O}^{2-}$ [28]. The doping leads to a metallic behaviour with ferro-magnetic interactions, see [11] and references therein. The electronic conductivity is further enhanced by an increase in the hybridization of the $\mathrm{Co} 3 d-\mathrm{O} 2 p$ orbitals due to an increase in the mean Co-O-Co bonding angle towards $180^{\circ}$ as the larger $\mathrm{Sr}^{2+}$ ions replace $\mathrm{La}^{3+}$ ions [29]. The formed oxygen vacancies improve the mobility of the oxygen ions and $\mathrm{La}_{1-\mathrm{x}} \mathrm{Sr}_{\mathrm{x}} \mathrm{CoO}_{3}$ is a mixed electronic and ionic conductor, an essential property for its use in SOFC electrodes or oxygen separating membranes [30].

In $\mathrm{YCoO}_{3}$, the smaller $\mathrm{Y}^{3+}$ leads to larger tilts of the octahedra and smaller Co-O-Co angles. This decreases the hybridization of the $\mathrm{Co} 3 d-\mathrm{O} 2 p$ orbitals and shortens the Co-O bonds, which in turn causes a larger crystal field splitting of $\mathrm{Co}^{3+}$ that shifts the LS $\rightarrow$ IS $\rightarrow$ HS spin transitions in $\mathrm{Co}^{3+}$ to higher temperatures, thus decreasing the thermal expansion coefficient and the electronic conductivity by shifting them to higher temperatures [31,32].

An alternative way to change the properties of $\mathrm{LaCoO}_{3}$ and similar compounds is to substitute $\mathrm{Co}$ in the B position by another ion of different charge and thus change the formal valence of Co. Several studies have been carried out in the system $\mathrm{LaCo}_{1-x} \mathrm{Ti}_{x} \mathrm{O}_{3}$, where $\mathrm{Ti}^{4+}$ is substituted for $\mathrm{Co}^{3+}[11,33,34]$. A solid solution is found to exist up to $x=0.5$ [34]. For every $\mathrm{Co}^{3+}$ substituted by the smaller $\mathrm{Ti}^{4+}$, one $\mathrm{Co}^{3+}$ is reduced to a larger $\mathrm{Co}^{2+}$ to keep charge neutrality, i.e. 
$\mathrm{LaCo}_{1-2 x}^{3+} \mathrm{Co}_{x}^{2+} \mathrm{Ti}_{x}^{4+} \mathrm{O}_{3}$. The observed symmetry is $R \overline{3} c$ for $0 \leq \mathrm{x} \leq 0.2$ and then gradually changes to orthorhombic Pbnm for $\mathrm{x} \geq 0.25$. For $\mathrm{x}=0.4$ and 0.5 , when the amount of the $\mathrm{Ti}^{4+}$ and $\mathrm{Co}^{2+}$ is high enough, the Ti and Co atoms start to order and a double perovskite forms with symmetry $P 2_{1} / n$. The structure is illustrated in Fig. 1 . The observed lattice expansion is thus explained by an increasing amount of $\mathrm{Co}^{2+}$ ions with larger ionic radius than those of $\mathrm{Co}^{3+}$ and $\mathrm{Ti}^{4+}$ [22].

The effects of the substitution of Co by Ti upon the electronic structure and magnetic properties are complex and have been discussed in detail by many authors $[11,29,35]$. Álvarez-Serrano et al. [34] concluded that $\mathrm{Co}^{3+}$ is for $\mathrm{x}<0.25$ in all three LS, IS and HS states, with the two latter being responsible for weak ferromagnetic interactions, whereas for $\mathrm{x}>0.25$ the LS state is predominant and the $\mathrm{Co}^{2+}$ ions contribute to antiferromagnetic interactions.

Substitution of $\mathrm{Co}^{3+}$ with $\mathrm{Mg}^{2+}$ in $\mathrm{LaCo}_{1-\mathrm{x}} \mathrm{Mg}_{\mathrm{x}} \mathrm{O}_{3}$ system is less investigated $[15,36]$. Successful substitutions have been reported up to $\mathrm{x}=0.1$ by Ramandass et al. [36] and up to $\mathrm{x}=0.5$ by Parkash et al. [15]. The latter group found the compounds to be orthorhombic and that the oxidation state of $\mathrm{Co}$ is $3+$ for all samples indicating that the insertion of $\mathrm{Mg}$ is accommodated by the formation of oxygen vacancies rather than oxidation of $\mathrm{Co}^{3+}$ to $\mathrm{Co}^{4+}$. The activation energy for conduction increases for $\mathrm{x}>$ 0.2 due to breakage of the Co-O-Co links responsible for electronic conduction.

In the present paper we report on the characterisation of perovskite-type phases formed in the system $\mathrm{La}_{2} \mathrm{Co}_{1+z}\left(\mathrm{Mg}_{\mathrm{x}} \mathrm{Ti}_{1-x}\right)_{1-\mathrm{z}} \mathrm{O}_{6}$. Double doping in this system is of interest as it gives the possibility to investigate how a change in Co oxidation state affects the structure and properties without varying the Co content. This effect can be studied along the $\mathrm{La}_{2} \mathrm{CoTiO}_{6}-\mathrm{La}_{2} \mathrm{CoMgO}_{6}$ compositional line. Secondly, the effect of changing the Co content keeping its oxidation state within the same system can be followed going towards $\mathrm{LaCoO}_{3}$. Investigated compositions are given in Table 1 and shown in the compositional diagram, with corners $\mathrm{La}_{2} \mathrm{CoTiO}_{6}-\mathrm{La}_{2} \mathrm{CoMgO}_{6}-$ $\mathrm{LaCoO}_{3}$, presented in Fig. 2. Along the line $\mathrm{La}_{2} \mathrm{CoTiO}_{6}-\mathrm{La}_{2} \mathrm{CoMgO}_{6}$, i.e. $\mathrm{z}=0$ and compositions $\mathrm{La}_{2} \mathrm{Co}\left(\mathrm{Mg}_{\mathrm{x}} \mathrm{Ti}_{1-\mathrm{x}}\right) \mathrm{O}_{6}$, the formal oxidation state of Co increases from $2+$ to $4+$ as $\mathrm{x}$ increases from 0 to 1 . Samples along this line were prepared in steps of $\Delta \mathrm{x}$ $=0.1$ and the characterisations focused on compositions with $\mathrm{x} \leq 0.6$, i.e. compounds for which the formal oxidation state of Co varies essentially between $2+$ and $3+$. Samples were also prepared for the selected values of $\mathrm{x}=0,0.25,0.50,0.75$ along the 
lines $\mathrm{La}_{2} \mathrm{Co}_{1+z}\left(\mathrm{Mg}_{\mathrm{x}} \mathrm{Ti}_{1-\mathrm{x}}\right)_{1-\mathrm{z}} \mathrm{O}_{6}-\mathrm{LaCoO}_{3}$ at $\mathrm{z}$ values of $0.2,0.4$ and 0.6. For these samples the characterisations were focused on compositions with $\mathrm{x}=0.50$, i.e. along the line $\mathrm{La}_{2} \mathrm{Co}\left(\mathrm{Mg}_{0.5} \mathrm{Ti}_{0.5}\right) \mathrm{O}_{6}-\mathrm{LaCoO}_{3}$, where $\mathrm{Co}$ has a formal oxidation state of $3+$.

\section{Experimental}

\subsection{Sample preparation}

Samples were prepared using the citrate route in order to increase the homogeneity of the starting mixture of the elements. The oxides $\mathrm{La}_{2} \mathrm{O}_{3}$ (Aldrich, 99.99\%) and $\mathrm{MgO}$ (Merck, analytical grade), pre-dried at $950^{\circ} \mathrm{C}$ for $24 \mathrm{~h}$, were dissolved at $\mathrm{pH} \approx 0.8$ together with cobalt(II) acetate tetrahydrate (Sigma Aldrich, reagent grade) and anhydrous citric acid (Merck, $\geq 99 \%$ ) in deionised water under stirring at a temperature of $90^{\circ} \mathrm{C}$. The amount of citric acid used corresponded to three times the total positive charge of the cations. Titanium (IV) butoxide (Sigma-Aldrich, 97.0 $\mathrm{wt} \%$ ) was thereafter added to the solution, whereupon a white precipitate of hydrated titanium oxide formed and then dissolved after a few minutes. The $\mathrm{pH}$ was then raised to $8.5-9$ by slowly adding ammonium hydroxide (VWR, 28\%) and the solution left standing for one hour. The solution was transferred to a porcelain dish on a heating plate and water evaporated at $300^{\circ} \mathrm{C}$ until a viscous gel formed. The gel was heated in air to $900^{\circ} \mathrm{C}$ at a rate of $5^{\circ} \mathrm{C} / \mathrm{min}$ and held at $900^{\circ} \mathrm{C}$ for $2 \mathrm{~h}$ in order to burn off the organic parts. Thermogravimetric analyses of the calcined samples revealed $2-4 \mathrm{wt} \%$ residues left. The resulting voluminous powder was thereafter grinded, pressed and fired in air twice at $1350^{\circ} \mathrm{C}$ for $24 \mathrm{~h}$, with intermediate grinding and pressing.

\subsection{Characterisation}

Thermogravimetric analyses of the starting materials were made with a Perkin Elmer TGA7 thermogravimetric analyzer.

XRPD patterns were collected with PANalytical X'pert PRO MPD diffractometer using $\mathrm{Cu}-K_{\alpha}$ radiation, variable slits with a constant area of $4 \mathrm{~cm}^{2}$ irradiated, and a step size of $0.0167^{\circ}$, in the $2 \theta$ range $10-80^{\circ}$ and with a total measuring time of $30 \mathrm{~min}$, yielding patterns with maximum peak intensities of $c a$. 50000. The patterns were converted to corresponding $0.5^{\circ}$ fixed slit data and $\mathrm{K}_{\mathrm{\alpha} 2}$ peaks stripped using the PANalytical X'Pert HighScore Plus software. Structure 
refinements were made with the FULLPROF software package [37]. Time-of-flight NPD data were collected on the GEM diffractometer at the spallation source ISIS, Rutherford Appleton Laboratory, U. K. Rietveld structure refinements were made with the GSAS program [38].

Electron diffraction (ED) patterns where recorded with a JEOL JEM2000FX TEM with $\mathrm{LaB}_{6}$ filament, equipped with a double tilt sample holder $\left( \pm \sim 45^{\circ}\right)$, operating at $200 \mathrm{kV}$, The sample was fixed on a copper grid with holey carbon by dipping the grid through an ethanol suspension of the sample.

Cation compositions were determined by energy dispersive spectroscopy (EDS) micro-analysis with a JEOL 7000F SEM operated at 20kV with an Oxford Inca Energy EDS system, using a special sample holder for TEM grids. The data were evaluated with fixed oxygen stoichiometry for the ZAF correction. EDS analysis was carried out for selected samples to rule out significant element losses during the syntheses. They were made using TEM grids in order to have well dispersed particles with sizes $>2 \mu \mathrm{m}$. The oxygen stoichiometry was fixed by stoichiometry in order to get a good approximation of the element matrix for the ZAF correction.

Magnetic susceptibility was recorded with a Quantum design physical property measurement system (PPMS) equipped with a vibrating sample magnetometer (VSM) with DC magnetization. Zero-field cooled (ZFC) and field cooled (FC) measurements, with an applied field of 1000 Oe, were made between 305 and $4 \mathrm{~K}$.

XANES spectra were recorded at National Synchrotron Radiation Research Center (NSRRC), Hsinchu, Taiwan. Ti- $L, \mathrm{Co}-L$ and $\mathrm{O}-K$ edges were collected at BL20A beam line, Ti- $K$ edges at BL16A beam line and Co- $K$ edges at BL01C beam line. Fluorescence-yield detection was used for $\mathrm{O}-K$, Ti- $K$ and Co- $K$ edges and totalelectron-yield detection for Ti- $L$ and Co- $L$ edges. Pre-edge background subtraction and normalization was done for the measured data sets and $K$-edge data was additionally corrected for the self-absorption effects using ATHENA [39] software. Rising edge background was determined and subtracted from the Co- $L_{2,3}$ spectra in order to determine the centers of gravity and areas of each branch through numerical integration. Peak-fitting into the $\mathrm{O}-\mathrm{K}$ edge $\mathrm{Co} / \mathrm{Ti}-\mathrm{O} 2 p$ hybrid structures was done using WINXAS [40] software. 


\section{Results}

\subsection{Phase analysis}

The perovskite-type phases observed for different compositions are given in Table 1 and marked in the phase diagram in Fig. 2. Four structure types were found; monoclinic $P 2_{1} / n$, orthorhombic Pbnm, rhombohedral $R \overline{3} c$ and cubic $P m \overline{3} m$. The monoclinic symmetry allows for an ordering of the B cations, whereas the other symmetries (i.e. Pbnm, $R \overline{3} c$ and $P m \overline{3} m$ ) have only one unique crystallographic $\mathrm{B}$ atom position.

Samples along the line $\mathrm{La}_{2} \mathrm{CoTiO}_{6}-\mathrm{La}_{2} \mathrm{CoMgO}_{6}$, i.e. $\mathrm{La}_{2} \mathrm{Co}\left(\mathrm{Mg}_{\mathrm{x}} \mathrm{Ti}_{1-\mathrm{x}}\right) \mathrm{O}_{6}$, were for $\mathrm{x} \leq 0.2$ found to be phase-pure monoclinic and for $\mathrm{x}=0.3$ and 0.4 phase-pure orthorhombic. For some of these compositions the distinction between monoclinic and orthorhombic symmetry could not be made reliably on basis of XRPD data alone and was therefore made by using ED (see below). For samples with $\mathrm{x} \geq 0.5$, the main reflections in their XRPD patterns could be assigned to mixtures of rhombohedral $R \overline{3} c$ and cubic $P m \overline{3} m$ perovskites, with the relative fraction of cubic phase varying between 30 and $50 \mathrm{wt} \%$. (The fraction of phases have been deduced from Rietveld refinements.) In addition the sample with $\mathrm{x}=0.5$ contained $c a .1 \mathrm{wt} \% \mathrm{La}_{2} \mathrm{O}_{3}$ and the sample with $\mathrm{x}=0.6 \mathrm{ca}$. $3 \mathrm{wt} \% \mathrm{La}_{2} \mathrm{CoO}_{4}$. Samples with $\mathrm{x} \geq 0.7$ were not pure, containing $3-5 \mathrm{wt} \% \mathrm{MgO}$ and considerable amounts of $\mathrm{La}_{2} \mathrm{O}_{3}$ and $\mathrm{La}(\mathrm{OH})_{3}$ that increased with increasing $\mathrm{x}$. Samples with $\mathrm{x}>0.2$ were all black and for $\mathrm{x} \leq 0.2$ the colour changed gradually to beige with decreasing $\mathrm{x}$, indicative of an increase in a band gap following a decrease of the number of Co-O-Co links by ordering of the $\mathrm{B}$ atoms.

All prepared samples with more than $50 \mathrm{~mol} \%$ of Co atoms on the B sites were by XRPD found to contain only insignificant amounts of impurity phases $(\leq c a .0 .5$ wt\%). Samples near to the $\mathrm{La}_{2} \mathrm{CoTiO}_{6}$ corner were found to be monoclinic and, further away, orthorhombic. The $\mathrm{La}_{2} \mathrm{Co}_{1.6}\left(\mathrm{Mg}_{\mathrm{x}} \mathrm{Ti}_{1-\mathrm{x}}\right)_{0.4} \mathrm{O}_{6}$ samples near the $\mathrm{LaCoO}_{3}$ corner, as well as the $\mathrm{La}_{2} \mathrm{Co}_{1.4}\left(\mathrm{Mg}_{0.5} \mathrm{Ti}_{0.5}\right)_{0.6} \mathrm{O}_{6}$ and $\mathrm{La}_{2} \mathrm{Co}_{1.4}\left(\mathrm{Mg}_{0.25} \mathrm{Ti}_{0.75}\right)_{0.6} \mathrm{O}_{6}$ samples, were phase pure rhombohedral. The remaining compositions $\mathrm{La}_{2} \mathrm{Co}_{1.2}\left(\mathrm{Mg}_{0.75} \mathrm{Ti}_{0.25}\right)_{0.8} \mathrm{O}_{6}, \quad \mathrm{La}_{2} \mathrm{Co}_{1.2}\left(\mathrm{Mg}_{0.5} \mathrm{Ti}_{0.5}\right)_{0.8} \mathrm{O}_{6}$ and $\mathrm{La}_{2} \mathrm{Co}_{1.4}\left(\mathrm{Mg}_{0.75} \mathrm{Ti}_{0.25}\right)_{0.6} \mathrm{O}_{6}$ were mixtures of rhombohedral and cubic perovskites. 
The EDS analysis results agreed within error with the nominal compositions, e.g. 49(1) \% La, 25(1) \% Co and 26(1) \% Ti for $\mathrm{La}_{2} \mathrm{CoTiO}_{6}$ (45 point analyses) and 48(2) \% La, 26(3) \% Co, 14(3) \% Mg and 13(2) \% Ti for $\mathrm{La}_{2} \mathrm{CoMg}_{0.5} \mathrm{Ti}_{0.5} \mathrm{O}_{6}$ (65 point analyses), with standard deviations of the recorded percentages in parentheses.

\subsection{Electron diffraction}

The distinction between monoclinic and orthorhombic symmetry could for some compositions not be made reliably from XRPD data and selected area ED (SAED) patterns were used for these samples to determine the symmetry. For each of the space groups $P 2_{1} / n, P b n m, R \overline{3} c$ there exists an $[110]_{\mathrm{p}}$ direction with a unique set of superstructure reflections (see Fig. 3). The unique reflection condition that distinguishes $P b n m$ from $P 2_{1} / n$ is $0 k l: k=2 n$ present in $P b n m$ (for which there is a lack of $\mathrm{B}$ cation ordering) but not in $P 2_{1} / n$. (see Fig. $3 \mathrm{a}$ and $3 \mathrm{~b}$, respectively). The $R \overline{3} c$ symmetry assigned to samples by XRPD was also confirmed by SAED patterns, as evidenced by a lack of superstructure reflections in one of the $[110]_{\mathrm{p}}$ directions (see Fig. 3c).

\subsection{X-ray powder diffraction}

All samples were characterised by means of Rietveld refinements. However, the studies were focused on the samples $\mathrm{La}_{2} \mathrm{Co}_{1+\mathrm{z}}\left(\mathrm{Mg}_{\mathrm{x}} \mathrm{Ti}_{1-\mathrm{x}}\right)_{1-\mathrm{z}} \mathrm{O}_{6} 0 \leq \mathrm{x} \leq 0.6, \mathrm{z}=0$ and $\mathrm{x}$ $=0.5$ and $0 \leq \mathrm{z} \leq 0.6$. The corresponding diffraction patterns are shown in Fig. 4. The number of parameters refined varied between 15 and 26, including a fifth-order background polynomial, unit-cell parameters, atomic positions, a collective thermal parameter for each phase and, in the cases of $P 2_{1} / n$ symmetry, site occupancy factors (sof' s) for the two different B sites.

For samples that contained only one perovskite-type structure, i.e. either $P 2_{1} / n, P b n m$ or $R \overline{3} c$, good fits were achieved with $\chi^{2}$ values close to 1 , while for mixtures of $R \overline{3} c$ and $\operatorname{Pm} \overline{3} m$ phases the fits were worse, with $\chi^{2}$ values varying between 3 and 4 . The half-widths of the reflections were comparatively sharp for the monoclinic and orthorhombic phases, slightly broader for the rhombohedral phases, 
and very broad, $c a .0 .5^{\circ}$, for the cubic phases. The sample peak broadenings are considered further in the discussion section.

The $P 2_{1} / n$ and $P b n m$ symmetry phases were found to be, to a varying degree, pseudo-cubic, i.e. their unit cell parameters are geometrically related, and in the case of $P 2_{1} / n$ the $\beta$ angle is very close to $90^{\circ}$. Because of the resulting strong overlap of Bragg peaks, and strong correlations between O-atom position parameters, refinements for the $P 2_{1} / n$ phases did not converge unless parameter shifts were damped. A damping factor of 0.1 was therefore used for the atom position parameter shifts for the $P 2_{1} / n$ as well as the Pbnm phases. As a consequence of the peak overlap the estimated standard deviations (esd's) for O-atom positions, and therefore derived B-O distances, are quite large. However, we believe that the data are of sufficient quality to provide information about average B-O distances.

In the refinements, B-site occupancies were also refined. For the Pbnm and $R \overline{3} c$ phases, with only one B-atom position, only Co atoms were placed on the site and the sof refined. For the Mg-containing $P 2_{1} / n$ phases, with two unique $\mathrm{B}$ sites, all $\mathrm{Mg}$ atoms were in the starting model tentatively placed on one site and an amount of Co atoms corresponding, with respect to electrons, to the sum of Co and $\mathrm{Ti}$ atoms allowed to distribute over the two sites. The refined sof's, given in Tables 1, 2 and 3, are measures of the number of electrons on the sites and do not imply vacancies on them.

Crystallographic data for the $P 2_{1} / n, P b n m$ and $R \overline{3} c$ symmetry phases from Rietveld refinements using XRPD data are given in Tables 2, 3, and 4, respectively. The esd' $s$ in the tables have not been corrected for serial correlation. Values of $\chi^{2}$ below 1 are due to an un-correct weighing scheme in the refinements, in turn a consequence of the conversion of the recorded variable-slit data to corresponding fixed-slit data. Corresponding selected inter-atomic distances and angles for the phases are given in Tables 5, 6 and 7.

The observed perovskite sub-cell volume is in Fig. 5 plotted as a function of $\mathrm{x}$ for the $\mathrm{La}_{2} \mathrm{Co}\left(\mathrm{Mg}_{\mathrm{x}} \mathrm{Ti}_{1-\mathrm{x}}\right) \mathrm{O}_{6}$ series (Fig. 5a) and versus $\mathrm{z}$ for the $\mathrm{La}_{2} \mathrm{Co}_{1+\mathrm{z}}\left(\mathrm{Mg}_{\mathrm{x}} \mathrm{Ti}_{1-\mathrm{x}}\right)_{1-}$ ${ }_{z} \mathrm{O}_{6}(\mathrm{x}=0.0,0.25,0.50,0.75)$ series (Fig. 5b). The decrease in volume with $\mathrm{x}$ in the former series is attributable to the increasing substitution of $\mathrm{Co}^{2+}$ ions by smaller $\mathrm{Co}^{3+}$ ions up to $\mathrm{x}=0.5$. For higher $\mathrm{x}$-values the decrease (although much smaller) can be explained by a replacement of $\mathrm{Co}^{3+}$ by $\mathrm{Co}^{4+}$ if the latter is present in the compounds, 
which is not likely, see introduction. Two possibilities for the oxidation state of Co to remain $3+$ are; i) formation of oxygen vacancies (The formation of large amounts of oxygen vacancies are normally not consistent with decreasing sub-cell volumes, but cannot be excluded.) or ii) oxidation (ligand hole formation) of the $\mathrm{O}^{2-}$ ions. (This is in fact indicated by the XANES studies discussed below.) However, the unit cell volumes are for $x>0.5$ uncertain due to the presence of secondary phases. The decrease in volume with increasing $\mathrm{z}$ in the latter series can in the same way be attributed to an increasing amount of $\mathrm{Co}^{3+}$.

The compositional dependence of the variation of average octahedron $\mathrm{B}-\mathrm{O}$ inter-atomic distances are shown in Fig. 6 as a function of $x$ in the series $\mathrm{La}_{2} \mathrm{Co}\left(\mathrm{Mg}_{\mathrm{x}} \mathrm{Ti}_{1-\mathrm{x}}\right) \mathrm{O}_{6}$ and as a function of $\mathrm{z}$ in the series $\mathrm{La}_{2} \mathrm{Co}_{1+\mathrm{z}}\left(\mathrm{Mg}_{0.5} \mathrm{Ti}_{0.5}\right)_{1-\mathrm{z}} \mathrm{O}_{6}$. The $\mathrm{B}-\mathrm{O}$ distances decrease in both series smoothly with increasing fraction of $\mathrm{Co}^{3+}$ ions on the $\mathrm{B}$ sites. For the former series, the decrease in $\mathrm{B}-\mathrm{O}$ distance with increasing $\mathrm{X}$ follows that expected for $\mathrm{Co}^{3+}$ in a HS state for $\mathrm{x} \leq 0.2$, while for higher $\mathrm{x}$ values, and for the series viewed as a whole, the decrease lies between those expected for HS and LS states. These data suggest that the spin state of $\mathrm{Co}^{3+}$ is for higher $\mathrm{Co}^{3+}$ contents intermediate between HS and LS states and independent of composition for the studied samples, while it is HS in the $P 2_{1} / n$ phases. The latter is in contrast to what reported by Alvarez- Serrano et al. [34] suggesting LS for the compounds with $\mathrm{La}_{2} \mathrm{Co}_{1-\mathrm{x}} \mathrm{Ti}_{\mathrm{x}} \mathrm{O}_{6}$ where $\mathrm{x}>0.25$.

\subsection{Neutron powder diffraction}

The structures of monoclinic $P 2_{1} / n \quad \mathrm{La}_{2} \mathrm{CoTiO}_{6}$, orthorhombic Pbnm $\mathrm{La}_{2} \mathrm{Co}\left(\mathrm{Mg}_{0.3} \mathrm{Ti}_{0.7}\right) \mathrm{O}_{6}$ and rhombohedral $R \overline{3} c+$ cubic $P m \overline{3} m \mathrm{La}_{2} \mathrm{Co}\left(\mathrm{Mg}_{0.5} \mathrm{Ti}_{0.5}\right) \mathrm{O}_{6}$ were refined from time-of-flight NPD data. Refined parameters are given in Table 8 and selected inter-atomic distances in Table 9. The fit between observed and calculated patterns are shown in Fig. 7.

The neutron data provided superior information about A - O and B - O interatom distances and site occupancies on the $\mathrm{B}$ sites, the latter partly due to the negative neutron cross section of Ti. The esd's for the B - O distances were for the NPD data overall $0.003 \AA$ or better. The $\mathrm{BO}_{6}$ octahedra are found to be regular for the monoclinic and orthorhombic phases and the average $\mathrm{B}-\mathrm{O}-\mathrm{B}$ angles to be similar for all three phases: 156,159 , and $161^{\circ}$, respectively. The Rietveld refinements did not indicate the presence of oxygen vacancies. This is consistent with 
thermogravimetric studies in air and $\mathrm{N}_{2}(\mathrm{~g})$ of $\mathrm{La}_{2} \mathrm{Co}\left(\mathrm{Mg}_{0.5} \mathrm{Ti}_{0.5}\right) \mathrm{O}_{6}$ showing no significant change in weight upon heating. The refined parameters for $\mathrm{La}_{2} \mathrm{CoTiO}_{6}$ are in agreement, although not identical, with those reported by Rodriguez et al. [35,41]. The ordering of $\mathrm{Co}$ and $\mathrm{Ti}$ atoms is here found to be nearly complete, with $0.925(5)$ $\mathrm{Co}$ and $0.075(5) \mathrm{Ti}$ on one of the $\mathrm{B}$ atom sites. The average $\mathrm{B}-\mathrm{O}$ distance for the

octahedron containing predominantly Co is slightly larger, $2.059 \AA$, than for the other, $1.961 \AA$, in agreement with that $\mathrm{Co}^{2+}$ is a larger ion than $\mathrm{Ti}^{4+}$. The La atom is surrounded by $8 \mathrm{O}$ atoms at distances between 2.421(2) and 2.792(5) $\AA$, forming a distorted bi-capped trigonal prism.

For the $\mathrm{La}_{2} \mathrm{Co}\left(\mathrm{Mg}_{0.5} \mathrm{Ti}_{0.5}\right) \mathrm{O}_{3}$ sample the composition on the $\mathrm{B}$ site was refined individually for the rhombohedral $R \overline{3} c$ phase and the cubic $P m \overline{3} m$ phase by constraining the overall composition to be equal to the nominal one. The refined sof's, given in Table 7, are in our view uncertain, but they suggest that the cubic phase contains more $\mathrm{Ti}$, and thus less $\mathrm{Mg}$ and $\mathrm{Co}$, compared to the rhombohedral phase.

\subsection{Magnetic susceptibility}

The temperature variations of the molar susceptibility $\chi_{\mathrm{m}}$ per Co atom, $1 / \chi_{\mathrm{m}}$, and the effective magnetic moments $\mu_{\text {eff, }}$ in units of Bohr magnetons (BM), are shown in Fig. 8 for the series $\operatorname{La}_{2} \mathrm{CoMg}_{\mathrm{x}} \mathrm{Ti}_{1-\mathrm{x}} \mathrm{O}_{6}(0 \leq \mathrm{x} \leq 0.5)$ and in Fig. 9 those of $1 / \chi_{\mathrm{m}}$ and $\mu_{\text {eff }}$ for the set of series along the lines $\mathrm{La}_{2} \mathrm{Co}\left(\mathrm{Mg}_{\mathrm{x}} \mathrm{Ti}_{1-\mathrm{x}}\right) \mathrm{O}_{6}-\mathrm{LaCoO}_{3}$ at values of $\mathrm{x}=0,0.25$, $0.50,0.75$. The samples with higher formal oxidation state of Co contains secondary phases such as $\mathrm{La}_{2} \mathrm{O}_{3}, \mathrm{La}(\mathrm{OH})_{3}$ and $\mathrm{La}_{2} \mathrm{CoO}_{4}$. The former two phases are diamagnetic and the contribution to the magnitude susceptibility are in the size of the background i.e. $10^{-6}-10^{-5}$ emu. The 3 wt- $\%$ of $\mathrm{La}_{2} \mathrm{CoO}_{4}$ found in the sample with $\mathrm{x}=0.6$ gives a significant contribution to the magnetic susceptibility, although no thermal spin state excitation is expected as $\mathrm{Co}^{2+}$ is already high spin. The secondary cubic phase observed for the rhombohedral phases has a very similar perovskite sub-cell edge i.e. $\sim 3.87-3.87 \AA$ differing only by $0.01 \AA$ indicating a very similar composition of the two phases.

For the series $\mathrm{La}_{2} \mathrm{CoMg}_{\mathrm{x}} \mathrm{Ti}_{1-\mathrm{x}} \mathrm{O}_{6}$, there are anti-ferromagnetic transitions at $c$ a. $15 \mathrm{~K}$ for $x=0$ and 0.1 and at $c a .8 \mathrm{~K}$ for $\mathrm{x}=0.2$. This agrees with the findings of Rodriguez et al. [41], who reported a monoclinic anti-ferromagnetic structure of type 
II for $\mathrm{La}_{2} \mathrm{CoTiO}_{6}$. For all other compositions, including those in the other series, the FC and ZFC curves overlap, which implies that ferromagnetic interactions in the materials are small. The susceptibility follows for $0 \leq \mathrm{x} \leq 0.4$ approximately a CurieWeiss law at $100-295 \mathrm{~K}$, while for higher $\mathrm{x}$ values the $1 / \chi_{\mathrm{m}} v s$. T curves are markedly curved, with the curvature increasing with $\mathrm{x}$.

Room temperature $\mu_{\text {eff }}$ values were calculated using linear regions within 150 $295 \mathrm{~K}$ for samples that followed a Curie-Weiss law and from the relation $\mu_{\text {eff }}^{2}=$ $8 \cdot \chi_{\mathrm{m}} \cdot \mathrm{T}$ at $\mathrm{T}=250-295 \mathrm{~K}$ for the others. The $\mu_{\mathrm{eff}}$ values decrease with increasing $\mathrm{x}$ as the formal oxidation state of the Co changes from $2+$ to $3+$, as shown in Fig. 10. The decrease is similar to that found for $0.25 \leq \mathrm{x} \leq 0.5$ in the $\mathrm{LaCo}_{1-\mathrm{x}} \mathrm{Ti}_{\mathrm{x}} \mathrm{O}_{3}$ system [34]. The observed $\mu_{\text {eff }}$ for samples with low Mg contents, containing Co mainly in a $2+$ state, are higher than the spin-only value $\left(\mu_{\mathrm{SO}}\right)$ of $3.87 \mathrm{BM}$ for a $\mathrm{HS}\left(t_{2 g}{ }^{5} e_{g}{ }^{2}\right) d^{7}$ system with ${ }^{4} T_{1 \mathrm{~g}}$ ground term. This is common for $\mathrm{Co}^{2+}$ ions and can be attributed to spinorbit coupling [42]. The $\mu_{\text {eff }}$ for an isolated $\mathrm{Co}^{2+}$ ion in an octahedral (cubic) crystal field is according to the expressions given in [42], and a spin-orbit coupling constant of $\lambda \approx-170 \mathrm{~cm}^{-1}$, expected to reach a plateau of $4.65-5.2 \mathrm{BM}$ at $200-300 \mathrm{~K}$, depending on the strength of the crystal field, and the susceptibility to obey approximately a Curie-Weiss law $\left(\chi=\frac{C}{T-\Theta}\right)$ above $c a .100 \mathrm{~K}$ with $\theta \approx-20^{\circ}$. The $\mu_{\text {eff }}$ for the samples with mainly $\mathrm{Co}^{3+}$ are in the mid range between those expected for a (diamagnetic) LS $\left(t_{2 g}{ }^{6} e_{g}{ }^{0}\right){ }^{1} A_{1 \mathrm{~g}}$ ground term and a HS $\left(t_{2 g}{ }^{4} e_{g}{ }^{2}{ }^{5} T_{2 \mathrm{~g}}\right.$ ground term. This is well known from the literature for similar Co containing systems, notably $\mathrm{LaCoO}_{3}$, and has been explained either in terms of distributions of $\mathrm{Co}^{3+}$ in HS and LS states or $\mathrm{Co}^{3+}$ with an IS $\left(t_{2 g}{ }^{5} e_{g}\right)^{1} T_{1 \mathrm{~g}}$ ground term [8]. Discussions about which of these interpretations is correct is currently ongoing (see e.g. [17]).

Considering the data for all compositions, the curves shown in Fig.'s 8 and 9 show additional noteworthy features. First, the phases for which the susceptibility follows approximately a Curie-Weiss law are, with the exception of the rhombohedral $\mathrm{La}_{2} \mathrm{Co}_{1.4}\left(\mathrm{Mg}_{0.25} \mathrm{Ti}_{0.75}\right)_{0.6} \mathrm{O}_{6}$, all the monoclinic and orthorhombic phases. The phases that do not exhibit Curie-Weiss behaviour are thus all rhombohedral and contain in comparison formally more $\mathrm{Co}^{3+}$. It seems natural therefore to associate the curved $1 / \chi_{\mathrm{m}}$ vs. $\mathrm{T}$ curves for these to increased fractions of $\mathrm{HS} \mathrm{Co}^{3+}$ with increasing temperature. Secondly, with the exception of one composition $\left(\mathrm{La}_{2} \mathrm{CoMg}_{0.6} \mathrm{Ti}_{0.4} \mathrm{O}_{6}\right)$, 
the $\mu_{\text {eff }}$ for all rhombohedral phases shows an increase with decreasing temperature for $\mathrm{T} \leq c a .25 \mathrm{~K}$. This is vaguely reminiscent of the susceptibility behaviour of $\mathrm{LaCoO}_{3}$ and has been explained as a surface effect by localised spins associated with surface cobalt order giving a weak ferromagnetism [8]. Thirdly, the $\mu_{\text {eff }}$ is for all samples small at low temperatures. For the paramagnetic monoclinic and orthorhombic phases, near the $\mathrm{La}_{2} \mathrm{CoTiO}_{6}$ corner, this might be due to local antiferromagnetic interactions and for the rhombohedral phases due to a $\mathrm{LS} \mathrm{Co}^{3+}$ state. Fourthly, samples that contain formally both $\mathrm{Co}^{3+}$ and $\mathrm{Co}^{4+}$ (i.e. $\mathrm{x}>0.5$ ) exhibit room temperature $\mu_{\mathrm{eff}}$ values that are similar to those that contain formally only $\mathrm{Co}^{3+}$. This suggests that the former might in fact contain only $\mathrm{Co}^{3+}$ and that the charge balance is maintained by mixture of oxygen vacancies and oxidation of the $\mathrm{O}^{2-}$ ions, as proposed to occur for $\mathrm{La}_{1-\mathrm{x}} \mathrm{Sr}_{\mathrm{x}} \mathrm{CoO}_{3}$ [28].

\subsection{XANES}

XANES spectra were recorded for the $\mathrm{La}_{2} \mathrm{Co}\left(\mathrm{Ti}_{1-\mathrm{x}} \mathrm{Mg}_{\mathrm{x}}\right) \mathrm{O}_{6}(0.0<\mathrm{x}<0.6)$ and $\mathrm{La}_{2} \mathrm{Co}_{1+\mathrm{z}}\left(\mathrm{Ti}_{0.5} \mathrm{Co}_{0.5}\right)_{1-\mathrm{z}} \mathrm{O}_{6}(0.0<\mathrm{z}<0.6)$ series. Within the studied substitution ranges, the formal oxidation state of Co changes between $2+$ and 3.2+. Transition-metal (TM)- $K$ edges are gathered in Fig. 11. Ti- and Co- $L_{2,3}$ edges are presented in Fig. 12 and 13, respectively. O- $K$ edges are shown in Fig. 14.

The chemical shifts $[43,44]$ of the $T M-K$ and $-L_{2,3}$ edges were used to analyse the redox behaviour. Ti- $K$ and $-L_{2,3}$ edges present no shifts with neither $\mathrm{x}$ nor $\mathrm{z}$ within the accuracy of the determination (See e.g. inset in Fig. 11 (a)). The relatively close match of the $\mathrm{Ti}-K$ edge with $\mathrm{Ti}^{4+} \mathrm{O}_{2}$ suggests $\mathrm{Ti}^{4+}$ in all the samples. Co- $K$ and $-L_{2,3}$ edges, on the other hand, both show clear positive shifts with increasing $\mathrm{x}$ (and formal oxidation state of $\mathrm{Co}$ ) indicating an increase in the actual oxidation state of Co. The shift in energy positions of the Co- $L_{2}(+0.7 \mathrm{eV})$ and $-L_{3}(+1.3 \mathrm{eV})$ edges (Fig. $\left.13(\mathrm{~b})\right)$ takes place till $\mathrm{x}=0.5$ (with formally $\mathrm{Co}^{3+}$ ), however, followed by a levelling-off for $\mathrm{x}=0.6$. The latter indicates the Co to be reluctant to increase its oxidation state above $3+$. Within the $\mathrm{La}_{2} \mathrm{Co}^{3+}{ }_{1+\mathrm{z}}\left(\mathrm{Ti}_{0.5} \mathrm{Mg}_{0.5}\right)_{1-\mathrm{z}} \mathrm{O}_{6}$ series the energy positions of the Co- $L_{2,3}$ edge spectra are independent of $z$. The consistence between the compositions containing formally $\mathrm{Co}^{3+}$ implies to a close match between the actual and formal Co oxidation states. The $\mathrm{La}_{2} \mathrm{Co}\left(\mathrm{Ti}_{1-\mathrm{x}} \mathrm{Mg}_{\mathrm{x}}\right) \mathrm{O}_{6} \mathrm{Co}-K$ edges exhibit a nearly linear positive shift $(+1.6 \mathrm{eV})$ with increasing $\mathrm{x}$ for the $\mathrm{Co} 4 p$ feature energy positions (inset in Fig. 
11 (b)). The rather large spread of the energy positions $(0.3 \mathrm{eV})$ for the Co $4 p$ feature in the $\mathrm{La}_{2} \mathrm{Co}_{1+\mathrm{z}}\left(\mathrm{Ti}_{0.5} \mathrm{Mg}_{0.5}\right)_{1-\mathrm{z}} \mathrm{O}_{6}$ series, where $\mathrm{Co}$ has a nominal oxidation state $3+$, indicates that the chemical shift between $\mathrm{x}=0.5$ and 0.6 in $\mathrm{La}_{2} \mathrm{Co}\left(\mathrm{Ti}_{1-\mathrm{x}} \mathrm{Mg}_{\mathrm{x}}\right) \mathrm{O}_{6}$ is within the error of the measurements. (It is known that the chemical shifts tend to be much stronger for $T M-K$ edges compared to $T M-L$ ones [43].)

The strengths of the crystal fields surrounding $\mathrm{Ti}$ and Co were estimated through comparing the profiles of their $L_{2,3}$ edge spectra with those of the published model spectra by van der Laan et al. [45] and de Groot et al. [46,47]. In the case of the $T i-L_{2,3}$ edge [46] (Fig. 12), splitting of both the A-B and the C-D main-features increase with increasing $x$. Evaluation of the splits [45] indicate an increase from 1.5 $-1.8 \mathrm{eV}$ to $2.1-2.4 \mathrm{eV}$ in the strength of the crystal field surrounding $\mathrm{Ti}$. In the case of the $C o-L_{2,3}$ edge $[45,47]$ (Fig. 13) the strongly split spectral profiles at low $\mathrm{x}$ values (formal oxidation state of Co closer to $2+$ ) agree well with the models of $\mathrm{a} \mathrm{Co}^{2+}$ in $\mathrm{a} \leq$ $0.5 \mathrm{eV}$ crystal field splitting. The split gradually decreases with increasing $\mathrm{x}$ (and increasing formal oxidation state of $\mathrm{Co}$ ), and the profiles of the $\mathrm{x}=0.5$ and 0.6 samples eventually resemble the model for $\mathrm{Co}^{3+}$ in $1.5-2.0 \mathrm{eV}$ crystal field (i.e. $\mathrm{x}=$ 0.5 and $z=0.0,0.2,0.4$, or 0.6 ). The observed increase in the strengths of both Tiand Co-surrounding crystal fields together with the expected consequential lowering of the spin-state of Co are in agreement with the observed lattice contraction, see Fig. 5.

The large separation of the Co- $L_{2}$ and $-L_{3}$ edges due to a strong spin-orbit coupling also allows more direct observation of the Co spin-state evolution by a quantification of the $L_{3} /\left(L_{3}+L_{2}\right)$ intensity relation, also known as the branching ratio $[44,48]$. The observed decrease (Fig. 13 (c)) supports a lowering of the spin state with increasing $\mathrm{x}$. The absolute values for the branching ratios, $0.73-0.82$, are somewhat higher than theoretical ones, 0.6 for LS and 0.7 for HS [44,48], which might be due to our background removal procedure. However, the range of evolution fits very well to the theoretical range. Similar to what observed for the energy position of the Co- $L_{2,3}$ edges a $\mathrm{z}$ independent levelling-off is observed for the branching ratio for samples with $\mathrm{x} \geq 0.5$ (formal oxidation state of $\mathrm{Co} \geq 3+$ ).

The O- $K$ edges (Fig. 14 (a)) include $\mathrm{Co} / \mathrm{Ti} 3 d-\mathrm{O} 2 p$ hybrid structures and their intensities provide information on the occupancy of the $\mathrm{Co} / \mathrm{Ti} 3 t_{2 \mathrm{~g}}$ and $\mathrm{Co} / \mathrm{Ti} 3 e_{\mathrm{g}}$ orbitals. The $\mathrm{Co} / \mathrm{Ti} 3 d-\mathrm{O} 2 p$ hybrid shows two prominent, partly overlapping features (Fig. 14 (b)). The low-energy feature, E, intensifies with increasing formal Co valence 
(and $\mathrm{x}$ ), while the feature at higher energy, $\mathrm{F}$, shows less variation in magnitude. The $\mathrm{E} /(\mathrm{E}+\mathrm{F}) /(1+\mathrm{z})$ intensity ratio reveals a linear dependency (Fig. 14 (c)) on formal Co valence suggesting the main component of the $\mathrm{Co} / \mathrm{Ti} 3 d-\mathrm{O} 2 p$ hybrid to originate from the $\mathrm{Co} 3 d-\mathrm{O} 2 p$ hybridization. In addition to the oxidation state of $\mathrm{Co}$, the intensity ratio depends linearly also on the Co stoichiometry of the compound. This is demonstrated by the $\mathrm{E} /(\mathrm{E}+\mathrm{F}) /(1+\mathrm{z})$ values of the $\mathrm{La}_{2} \mathrm{Co}^{3+}{ }_{1+\mathrm{z}}\left(\mathrm{Ti}_{0.5} \mathrm{Mg}_{0.5}\right)_{1-\mathrm{z}} \mathrm{O}_{6}$ series $(\mathrm{z}$ $>0$ ), which fall into the same linear correlation of $z=0$ samples, providing a good match with the value of the $\mathrm{La}_{2} \mathrm{Co}^{3+}\left(\mathrm{Ti}_{0.5} \mathrm{Mg}_{0.5}\right) \mathrm{O}_{6}$ sample. The considerably ionic character of the Ti-O bond cannot directly explain the virtual absence of the Ti3d-O $2 p$ component in the $\mathrm{O}-K$ edge, because spectra of $\mathrm{Ti}^{4+}$ based perovskites with clear Ti3 $d-\mathrm{O} 2 p$ hybrid can be found from the literature [49]. However, the more covalent character of the Co-O bond as compared with the Ti-O bond might channel the exited $\mathrm{O} 1 s$ electrons mostly to the band structure component having Co3d character.

Feature $\mathrm{F}$ is understood as having a strong $\operatorname{Co} 3 e_{g}(\uparrow)$ character, since in all cases of octahedral splitting this ends up to be the highest orbital. For an interpretation of the peak E we need to consider the evolution of the spin state of Co with increasing valence. For $\mathrm{La}_{2} \mathrm{Co}^{2+} \mathrm{TiO}_{6}$, the peak $\mathrm{E}$ appears as a very weak low-energy shoulder. The HS state of $\mathrm{Co}^{2+}$, obvious from the Co- $L_{2,3}$ edge data, necessitates to assign it to Co3t $t_{2 g}(\uparrow)$, which is the lowest unoccupied state in the HS configuration. $\mathrm{La}_{2} \mathrm{Co}^{3+} \mathrm{Mg}_{0.5} \mathrm{Ti}_{0.5} \mathrm{O}_{6}$ hosts lower-spin $\mathrm{Co}$ and therefore the character of the peak $\mathrm{E}$ needs to change towards $\mathrm{Co} 3 e_{g}(\downarrow)$. Because of the similar values of the $J$ coupling and crystal-field splitting, these orbitals are close to each other in energy and therefore likely to partially overlap. On the basis of our interpretation, the split between the two peaks should give the value of $J$ coupling constant at high $\mathrm{x}$. Interestingly the energy positions of the $\mathrm{E}$ and $\mathrm{F}$ features do not show any change. This could be a result of compensation of the enhanced crystal field splitting by lowering of the average $d$ orbital energy. The existence of two features with a fixed separation instead of smoothly increasing separation suggests that the overall oxidation state of Co is defined by the stoichiometric proportion of two species with fixed oxidation states, namely $\mathrm{Co}^{2+}$ and $\mathrm{Co}^{3+}$. Unlike with the chemical shifts and branching ratio in Co- $L_{2,3}$ edge data, intensification continues when formal Co valence $\geq 3+$. This might be due to $\mathrm{O} 2 p$ ligand hole formation, typical with oxide compounds containing transition metal cations with untypically high formal oxidation states $[28,50]$. 


\section{Discussion}

The main structural changes with composition are clear for the investigated $\mathrm{La}_{2} \mathrm{Co}_{1}$ ${ }_{z}\left(\mathrm{Mg}_{\mathrm{x}}-\mathrm{Ti}_{1-\mathrm{x}}\right)_{\mathrm{z}} \mathrm{O}_{6}$ system. Along the line $\mathrm{La}_{2} \mathrm{CoTiO}_{6}-\mathrm{La}_{2} \mathrm{CoMgO}_{6}(\mathrm{z}=0)$ the perovskite sub-cell volume decreases in a linear way with increasing $\mathrm{Mg}$ content, i.e. $\mathrm{x}$, as seen in Fig. 5a, due to a simultaneous substitution of $\mathrm{Co}^{2+}$ ions by smaller $\mathrm{Co}^{3+}$ ions up to $\mathrm{x}$ $=0.5$. A linear increase in $\mathrm{Co}^{3+}$ ion content is in agreement with the data from the magnetic and XANES measurements. The NPD data showed furthermore no indications of any significant vacancy formation in the structures including oxygen. With increasing $\mathrm{x}$, the symmetry changes from monoclinic to orthorhombic and then to rhombohedral. This is in accordance with the Goldschmidt tolerance factor, which increases from 0.94 to 0.97 as $\mathrm{x}$ increases from 0 to 0.5 . Additional factors that may promote an increase in symmetry are an increasing number of different B cations, causing an inability for these to order, and increasing micro-strains.

Similar structural changes are observed for the set of series $\mathrm{La}_{2} \mathrm{Co}_{1+z}\left(\mathrm{Mg}_{\mathrm{x}} \mathrm{Ti}_{1-}\right.$ $\mathrm{x})_{1-\mathrm{z}} \mathrm{O}_{6}$ with increasing $\mathrm{z}$ and fixed values of $\mathrm{x}$, with a decrease in sub-cell volume, see Fig. 5b, that is caused by an increasing amount of $\mathrm{Co}^{3+}$. For low $\mathrm{x}$ and $\mathrm{z}$ values the phases are monoclinic or orthorhombic, see Fig. 2, while the majority of them are rhombohedral.

According to the XRPD patterns, about half of the investigated rhombohedral $R \overline{3} c$ phases coexist with cubic $P m \overline{3} m$ perovskite phases. The latter having variable proportions between 20 and $50 \mathrm{wt} \%$. We have, however, not succeeded to unambiguously identify any cubic phase from the samples by SAED, as one of the pseudocubic $<1 \quad 1 \quad 0>_{\mathrm{p}}$ directions of the perovskite structure with rhombohedral $R \overline{3} c$ symmetry is identical to the corresponding one in the cubic $P m \overline{3} m$ symmetry. We have neither been able with certainty to establish, whether the proportions between the coexisting and rhombohedral phases differ. In addition to the structural characterisations that have been described for samples heat-treated at $1350^{\circ} \mathrm{C}$, samples heat-treated at temperatures of $600^{\circ} \mathrm{C}, 900^{\circ} \mathrm{C}$ and $1150^{\circ} \mathrm{C}$ were also analysed. SEM and TEM studies of these showed that the citrate route used produces initially $10-20 \mathrm{~nm}$ large coalesced nano-particles. XRPD patterns of samples heated to $600^{\circ} \mathrm{C}$ and $900^{\circ} \mathrm{C}$ showed very broad peaks of apparent cubic perovskite phases and those of samples heat-treated at $1150^{\circ} \mathrm{C}$ were very similar to those of samples heat-treated at $1350^{\circ} \mathrm{C}$, but with somewhat broader peaks. 
Sample peak broadening was observed in the XRPD patterns of all samples heat-treated at $1350^{\circ} \mathrm{C}$, indicating small domain sizes and/or strains. The monoclinic and orthorhombic phases showed relatively sharp peaks, with peak widths of 0.08 $0.15^{\circ}$ at $2 \theta=33^{\circ}$. The rhombohedral phases showed relatively large peak widths of $0.23-0.29^{\circ}$ for compositions with $\mathrm{z}=0$, but they decreased with increasing $\mathrm{z}$, down to $c a .0 .12^{\circ}$. The peaks from the cubic phases were very broad, $c a .0 .5^{\circ}$. If this width is attributed to solely small domains it corresponds to a domain size of $c a .150 \AA$. This suggests that the observed cubic phases may be stabilized by their small domain sizes and/or strains. Heat-treating several samples along the $\mathrm{La}_{2} \mathrm{CoTiO}_{6}-\mathrm{La}_{2} \mathrm{CoMgO}_{6}$ line for a further $348 \mathrm{~h}$ at $1350^{\circ} \mathrm{C}$ did, rather remarkably, not effect any substantial changes in peak widths or apparent relative amounts of the cubic phase.

The magnetic susceptibility measurements showed that for the rhombohedral phases, containing formally comparatively high amounts of $\mathrm{Co}^{3+} / \mathrm{Co}^{4+}$, the $1 / \chi_{\mathrm{m}} v s . \mathrm{T}$ curves are curved, i.e. $\mu_{\mathrm{eff}}$ increases with increasing temperature. This can be attributed to an increase in the amount of $\mathrm{HS} \mathrm{Co}^{3+}$ with increasing temperature.

The data that may clarify which spin state the $\mathrm{Co}^{3+}$ ions have in the present compounds, primarily along the line $\mathrm{La}_{2} \mathrm{CoTiO}_{6}-\mathrm{La}_{2} \mathrm{CoMgO}_{6}(\mathrm{z}=0)$, are of three kinds: observed average B-O distances, determined magnetic moments per Co atom and the XANES measurements. As mentioned above, the compositional dependence of the observed average B-O distances with $\mathrm{x}$, shown in Fig. 6, shows a slope for $\mathrm{x} \leq$ 0.2 which is similar to that expected if the $\mathrm{Co}^{3+}$ ions are in a HS state, while for the whole range of $\mathrm{x}$ between 0 and 0.5 the slope indicates a spin state for $\mathrm{Co}^{3+}$ between HS and LS. These data thus indicate that the spin state for $\mathrm{Co}^{3+}$ changes from a dominating HS for low $\mathrm{x}$ to a mixture of HS and LS at higher $\mathrm{x}$ values. This is supported by the XANES study, which indicates an increasing crystal field splitting. The observed room-temperature $\left(22^{\circ} \mathrm{C}\right)$, magnetic moment, shown in Fig. 10, decreases continuously from 4.8 $\mathrm{BM}$ for $\mathrm{x}=0$ to $2.1 \mathrm{BM}$ for $\mathrm{x}=0.5$. The value of 4.8

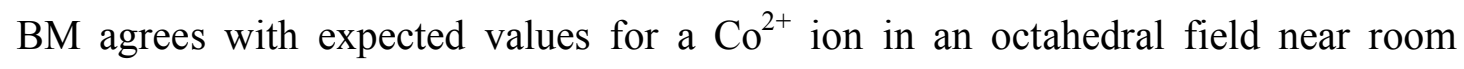
temperature of $4.65-5.2 \mathrm{BM}$ [42]. The value of $2.1 \mathrm{BM}$ for $\mathrm{x}=0.5$ is considerably smaller than an expected value of $\mathrm{HS} \mathrm{Co}^{3+}$ of $c a .5 .5 \mathrm{BM}$ [42], but higher than for LS $\mathrm{Co}^{3+}$, which ideally has no moment at all. Taking into account that the measured signal is proportional to the square of the moment, the value of $2.1 \mathrm{BM}$ corresponds to a mixture of about $15 \% \mathrm{HS}$ and $85 \% \mathrm{LS} \mathrm{Co}^{3+}$. This estimation of the percentage of 
$\mathrm{HS} \mathrm{Co}^{3+}$ is probably too low, considering that the crystal fields in these phases vary throughout the structures; depart to a varying degree from octahedral symmetry and a delocalization of electrons from the $t_{2 \mathrm{~g}}$ orbitals may occur, all of which are expected to decrease $\mu_{\text {eff }}$ for $\mathrm{Co}^{3+}$ [51]. The compositional variation of $\mu_{\mathrm{eff}}$ with $\mathrm{x}$, or more appropriately $\mu_{\text {eff }}^{2}$ with $\mathrm{x}$, is not entirely linear and indicates that the proportion of HS $\mathrm{Co}^{3+}$ decreases with increasing $\mathrm{x}$, as also indicated by the observed average B-O distances.

Unlike the magnetic data, the Co- $L_{2,3}$ edge branching ratio, see Fig. 13 (c), shows a clear linearly decreasing behaviour with increasing formal Co valence, contradicting the mentioned redistribution of spin states with oxidation. Taking into account the fixed energy positions of the O- $K$ edge E and F features, see Fig. 14 (c), which implies to the presence of two discrete Co valences, each spin state mixture should furthermore be assigned to a single $\mathrm{Co}$ valence $\left(\mathrm{Co}^{2+}\right.$ (higher-S) and $\mathrm{Co}^{3+}$ (lower-S).

In view of the differences between the results from magnetic measurements and XANES, at low x-values we can only conclude, that all the data taken together are compatible with $\mathrm{Co}^{3+}$ existing in these phases as a mixture of HS and LS states, and/or IS state, and that the proportions in the spin mixture are roughly independent of composition, yet higher proportion of $\mathrm{HS} \mathrm{Co}^{3+}$ might still exist in the monoclinic phases at low $\mathrm{x}$ and $\mathrm{z}$. For the samples with varying $\mathrm{z}$ and constant $\mathrm{x}$ it is clear that $\mu_{\text {eff }}$ decreases while replacing $\mathrm{Co}^{2+}$ with $\mathrm{Co}^{3+}$, while for the $\mathrm{x}=0.5$ and 0.75 samples no clear trends are observed, both having similar $\mu_{\mathrm{eff}}$ indicating that $\mathrm{Co}^{3+}$ is dominating in both series, i.e. no $\mathrm{Co}^{4+}$ is found in the $\mathrm{x}=0.75$ series.

\section{Conclusions}

The study shows that, excluding compositions with high Mg contents, perovskite type solid solutions exist in the pseudo ternary system $\mathrm{LaCoO}_{3}-\mathrm{LaCo}_{0.5} \mathrm{Ti}_{0.5} \mathrm{O}_{6}$ $\mathrm{LaCo}_{0.5} \mathrm{Mg}_{0.5} \mathrm{O}_{6}$. Close to the $\mathrm{LaCo}_{0.5} \mathrm{Ti}_{0.5} \mathrm{O}_{6}$ corner the structures are monoclinic and the $\mathrm{Co}$ and $\mathrm{Mg} / \mathrm{Ti}$ are ordered on the $\mathrm{B}$ atom positions. Away from this corner the symmetry changes via orthorhombic to rhombohedral, which is the dominating symmetry in the system. For larger $x$ and/or smaller $z$ in $\mathrm{La}_{2} \mathrm{Co}_{1+z}\left(\mathrm{Mg}_{\mathrm{x}} \mathrm{Ti}_{1-\mathrm{x}}\right)_{1-\mathrm{z}} \mathrm{O}_{6}$, the rhombohedral phases coexist with cubic perovskite phases. The perovskite sub-cell volume decreases both with increasing $\mathrm{Mg}$ and increasing $\mathrm{Co}$ content. XANES 
spectra for compositions $\mathrm{La}_{2} \mathrm{Co}\left(\mathrm{Mg}_{\mathrm{x}} \mathrm{T}_{1-\mathrm{x}}\right) \mathrm{O}_{6}$ with $0 \leq \mathrm{x} \leq 0.5$ confirm that the oxidation state of Co increases with $\mathrm{x}$ and that $\mathrm{Co}^{3+}$ has a spin state lower than HS. For higher $\mathrm{x}$ values with a formal valence for Co being higher than $3+$ the Co remains as $3+$ and the holes are formed on the $\mathrm{O}$ ions. XANES spectra of samples with formally only $\mathrm{Co}^{3+}$ do not show any significant differences. The magnetic susceptibly measurements show that $\mathrm{Co}^{3+}$ has a lower-spin state that is independent of composition, except possibly in the monoclinic phases, for which a HS state was indicated.

\section{Acknowledgements}

This work has been supported by the Swedish Research Council and Swedish Institute (Visbyprogramme). The electron microscopes and X-ray powder diffractometers used in this study were purchased from a grant by the Knut and Alice Wallenberg Foundation.

\section{References}

[1] R.H. Mitchell, Perovskites: Modern And Ancient, Almaz Press Inc., 2002.

[2] P.M. Woodward, Acta Crystallogr., Sect. B: Struct. Sci B53 (1997) 32-43.

[3] P.M. Woodward, Acta Crystallogr., Sect. B: Struct. Sci B53 (1997) 44-66.

[4] M.W. Lufaso, P.M. Woodward, Acta Crystallogr., Sect. B: Struct. Sci B60 (2004) 10-20.

[5] V.M. Goldschmidt, Naturwissenschaften 14 (1926) 477-485.

[6] J. Hakl, F.P. Châtel, S. Mészàros, K. Vad, Z. Klencsár, Z. Németh, E. Kuzmann, Z. Homonnay, A. Vértes, A. Simopoulos, E. Devlin, Y. Aoki, H. Konno, S. Kumar De, Solid State Sci. 11 (2009) 852-860.

[7] D.S. Tsvetkov, A.Y. Zuev, A.I. Vylkov, A.N. Petrov, Solid State Ionics 178 (2007) 1458-1462.

[8] M.A. Señarís-Rodriguez, J.B. Goodenough, J. Solid State Chem. 118 (1995) 323-336.

[9] W.F. Libby, Science 171 (1971) 499-500.

[10] A. Maignan, C. Martin, N. Nguyen, B. Raveau, Solid State Sci. 3 (2001) 57 63.

[11] D. Bahadur, O. Parkash, J. Solid State Chem. 46 (1983) 197-203. 
[12] J. Richter, P. Holtappels, T. Graule, T. Nakamura, L.J. Gauckler, Monatsh. Chem. 140 (2009) 985-999.

[13] J.A. Kilner, R. Brook, Solid State Ionics 6 (1982) 237-252.

[14] M. Cherry, M.S. Islam, C.R. Catlow, J. Solid State Chem. 118 (1995) 125132.

[15] O. Parkash, R. Kumar, C.D. Prasad, D. Kumar, J. Phys. D: Appl. Phys. 21 (1988) 1512-1515.

[16] R.J. Radwanski, Z. Ropka, ArXiv.org, E-Print Arch. Condens. Matter (2006) $1-4$.

[17] R. Eder, Phys. Rev. B: Condens. Matter 81 (2010) 1-10.

[18] T. Lorenz, Phys. Rev. B: Condens. Matter 66 (2002) 1-4.

[19] P.M. Raccah, J. Goodenough, Phys. Rev. 155 (1966) 932-943.

[20] A. Weber, E. Ivers-tiffe, D. Herbstritt, J. Eur. Ceram. Soc. 21 (2001) 18051811.

[21] R.V. Wandekar, B.N. Wani, S.R. Bharadwaj, Solid State Sci. 11 (2009) 240250 .

[22] R.D. Shannon, Acta Crystallogr., Sect. A: Found. Crystallogr. A32 (1976) 751-767.

[23] P.G. Radaelli, S. Cheong, Phys. Rev. B: Condens. Matter 66 (2002) 1-9.

[24] A. Podlesnyak, K. Conder, E. Pomjakushina, A. Mirmelstein, J. Magn. Magn. Mater. 310 (2007) 1552-1554.

[25] T. Horita, K. Yamaji, N. Sakai, H. Yokokawa, A. Weber, E. Ivers-tiffe, Electrochim. Acta 46 (2001) 1837- 1845.

[26] P. Ravindran, P.A. Korzhavyi, H. Fjellvåg, A. Kjekshus, Phys. Rev. B: Condens. Matter 60 (1999).

[27] T. Takami, J. Zhou, J.B. Goodenough, H. Ikuta, Phys. Rev. B: Condens. Matter 76 (2007) 1-7.

[28] A.R. Moodenbaugh, B. Nielsen, S. Sambasivan, D.A. Fischer, T. Friessnegg, S. Aggarwal, R. Ramesh, R.L. Pfeffer, Phys. Rev. B: Condens. Matter 61 (2000) 5666-5671.

[29] J.L. Hueso, J.P. Holgado, R. Pereñíguez, S. Mun, M. Salmeron, A. Caballero, J. Solid State Chem. 183 (2010) 27-32.

[30] A. Petric, P. Huang, F. Tietz, Solid State Ionics 135 (2000) 719-725.

[31] S. Uhlenbruck, F. Tietz, Mater. Sci. Eng., B 107 (2004) 277-282.

[32] K. Knízek, Z. Jirák, J. Hejtmánek, M. Veverka, M. Marysko, G. Maris, T.T. Palstra, ArXiv.org, E-Print Arch. Condens. Matter (2007) 1-24. 
[33] H. Nakatsugawa, E. Iguchi, J. Phys. Condens. Matter 11 (1999) 1711-1722.

[34] I. Álvarez-Serrano, G.J. Cuello, M.L. López, A. Jiménez-López, C. Pico, E. Rodríguez-Castellón, E. Rodríguez, M.L. Veiga, J. Phys. D: Appl. Phys. 41 (2008) 1-10.

[35] K. Holman, Q. Huang, T. Klimczuk, K. Trzebiatowski, J. Bos, E. Morosan, J. Lynn, R. Cava, J. Solid State Chem 180 (2007) 75-83.

[36] N. Ramadass, J. Gopalakrishnan, M.V. Sastri, J. Less-Common Met. 65 (1979) $129-138$.

[37] J. Rodriguez-Carvajal, T. Roisnel, Physica B 192 (1993) 55.

[38] A.C. Larson, R.B. Von Dreele, Los Alamos National Laboratory, Report LAUR (2000) 86-748.

[39] B. Ravel, M. Newville, J. Synchrotron Radiat. 12 (2005) 537-541.

[40] T. Ressler, J. Synchrotron Radiat. 5 (1998) 118-122.

[41] E. Rodríguez, M.L. López, J. Campo, M.L. Veiga, C. Pico, J. Mater. Chem. 12 (2002) 2798-2802.

[42] F.E. Mabbs, D.J. Machin, Magnetism And Transition Metal Complexes, Dover Publications Inc., 2008.

[43] R. Robert, D. Logvinovich, M.H. Aguirre, S.G. Ebbinghaus, L. Bocher, P. Tomeš, A. Weidenkaff, Acta Mater. 58 (2010) 680-691.

[44] Z. Hu, C. Grazioli, M. Knupfer, M.S. Golden, J. Fink, P. Mahadevan, A. Kumar, S. Ray, D.D. Sarma, S.A. Warda, D. Reinen, S. Kawasaki, M. Takano, C. Schüssler-Langeheine, C. Mazumdar, G. Kaindl, J. Alloys Compd. 343 (2002) 5-13.

[45] G. van Der Laan, I.W. Kirkman, J. Phys. Condens. Matter 4 (1992) 41894204.

[46] F.M. De Groot, J.C. Fuggle, B.T. Thole, G.A. Sawatsky, Phys. Rev. B: Condens. Matter 41 (1990) 928-937.

[47] F.M. de Groot, J.C. Fuggle, B.T. Thole, G.A. Sawatzky, Physical Review. B: Condensed Matter 42 (1990) 5459-5468.

[48] B. Thole, G. van Der Laan, Phys. Rev. B: Condens. Matter 38 (1988) 31583171 .

[49] A.S. Sefat, G. Amow, M.Y. Wu, G.A. Botton, J.E. Greedan, J. Solid State Chem. 178 (2005) 1008-1016.

[50] P. Kuiper, G. Kruizinga, J. Ghijsen, G.A. Sawatsky, H. Verweij, Phys. Rev. Lett. 62 (1989) 221-224.

[51] B.N. Figgis, M. Hitchman, Ligand Field Theory And Its Applications, First edit, John Wiley And Sons Ltd, 2000. 
[52] Y. Wu, M. Benfatto, M. Pedio, R. Cimino, S. Mobilio, S.R. Barman, K. Maiti, D.D. Sarma, Phys. Rev. B 56 2228-2233 (1997). 


\section{Figure captions.}

Fig. 1. Illustration of the double perovskite $P 2_{1} / n$ symmetry structure of $\mathrm{La}_{2} \mathrm{CoTiO}_{6}$ with alternating $\mathrm{Co}^{2+}$ (green) and $\mathrm{Ti}^{4+}$ (orange) octahedra.

Fig. 2. Compositional triangle with corners $\mathrm{La}_{2} \mathrm{CoTiO}_{6}-\mathrm{La}_{2} \mathrm{CoMgO}_{6}-\mathrm{LaCoO}_{3}$, showing prepared compositions and symmetries of the observed perovskite-type structures.

Fig. 3. Symmetry distinguishing SAED patterns for: (a) Monoclinic $P 2_{1} / n$ $\mathrm{La}_{2} \mathrm{CoMg}_{0.2} \mathrm{Ti}_{0.8} \mathrm{O}_{6}$ along $[100]_{\text {mon }}=[110]_{\mathrm{p}}$, with no systematic absences revealed due to the presence of weak superstructure reflections (some are marked with arrows). (The expected reflection condition $00 l ; l=2 n$ is not fulfilled due to double diffraction) (b) Orthorhombic Pbnm $\mathrm{La}_{2} \mathrm{CoMg}_{0.3} \mathrm{Ti}_{0.7} \mathrm{O}_{6}$ along [100 $]_{\text {ort }}=[110]_{\mathrm{p}}$, with reflection conditions $0 k l ; k=2 n$. The doubling of the perovskite c-axis $\left(c=2 c_{p}\right)$ gives rise to weak superstructure reflections (some are marked with arrows). (The reflection condition $00 l ; l=2 n$ is not fulfilled due to double diffraction) (c) rhombohedral, $R \overline{3} c$ $\mathrm{La}_{2} \mathrm{CoMg}_{0.5} \mathrm{Ti}_{0.5} \mathrm{O}_{6}$ along $[110]_{\text {rho }}=[110]_{\mathrm{p}}$, where no superstructure reflections are present. The contrast has been enhanced in order to easier visualise the weaker spots.

Fig. 4. Selected observed (small circles) and calculated (full lines) XRPD patterns for compositions along the lines $\mathrm{La}_{2} \mathrm{Co}\left(\mathrm{Mg}_{x} \mathrm{Ti}_{1-x}\right) \mathrm{O}_{6}$ and $\mathrm{La}_{2} \mathrm{Co}_{1+z}\left(\mathrm{Mg}_{0.5} \mathrm{Ti}_{0.5}\right)_{1-z} \mathrm{O}_{6}$. Positions of reflections from the cubic $P m \overline{3} m$ phases are indicated by asterisks.

Fig. 5. Perovskite sub-cell volume (a) as a function of $x$ in $\mathrm{La}_{2} \mathrm{Co}\left(\mathrm{Mg}_{x} \mathrm{Ti}_{1-x}\right) \mathrm{O}_{6}$ and (b) versus $z$ in $\mathrm{La}_{2} \mathrm{Co}_{1+z}\left(\mathrm{Mg}_{x} \mathrm{Ti}_{1-x}\right)_{1-z} \mathrm{O}_{6}$ for $\mathrm{x}=0.0,0.25,0.50,0.75$.

Fig. 6. Observed compositional dependence of the average octahedral B - O interatomic distances as a function of $x$ in $\mathrm{La}_{2} \mathrm{Co}\left(\mathrm{Mg}_{x} \mathrm{Ti}_{1-x}\right) \mathrm{O}_{6}$ and $z$ in $\mathrm{La}_{2} \mathrm{Co}_{1+z}\left(\mathrm{Mg}_{0.5} \mathrm{Ti}_{0.5}\right)_{1-z} \mathrm{O}_{6}$. The values for $x=0.0,0.3$ and 0.5 are from NPD data. The lines are indicated for theoretical estimates of B-O variation for HS (upper line) LS (lower line) using the Shannon ionic radii ${ }^{22}$ and an estimated oxygen radii of $1.342 \AA$. 
Fig. 7. Observed (crosses), calculated (line) and difference (bottom) time-of-flight NPD patterns for (a) monoclinic $P 2_{1} / n \mathrm{La}_{2} \mathrm{CoTiO}_{6}$, (b) orthorhombic Pbnm $\mathrm{La}_{2} \mathrm{Co}\left(\mathrm{Mg}_{0.3} \mathrm{Ti}_{0.7}\right) \mathrm{O}_{6}$, (c) rhombohedral $R \overline{3} c+$ cubic $P m \overline{3} m \mathrm{La}_{2} \mathrm{Co}\left(\mathrm{Mg}_{0.5} \mathrm{Ti}_{0.5}\right) \mathrm{O}_{6}$.

Fig. 8. Variation of (a) $\chi_{\mathrm{m}}\left(\mathrm{emu} / \mathrm{mole}^{*} \mathrm{Oe}\right)$, (b) $\left.1 / \chi_{\mathrm{m}}(\mathrm{Oe} * \mathrm{~mole} / \mathrm{emu})\right)$ and (c) $\mu_{\mathrm{eff}}$ (effective Bohr magnetons) with temperature for the series $\mathrm{La}_{2} \mathrm{CoMg}_{\mathrm{x}} \mathrm{Ti}_{1-\mathrm{x}} \mathrm{O}_{6}$.

Fig. 9. Variation of $1 / \chi_{\mathrm{m}}(\mathrm{Oe} * \mathrm{~mole} / \mathrm{emu})$ and $\mu_{\mathrm{eff}}$ (effective Bohr magnetons), respectively, with temperature for $\mathrm{La}_{2} \mathrm{Co}_{1+z}\left(\mathrm{Mg}_{\mathrm{x}} \mathrm{Ti}_{1-\mathrm{x}}\right)_{1-z} \mathrm{O}_{6}$ with $(\mathrm{a}, \mathrm{b}) \mathrm{x}=0$, $(\mathrm{c}, \mathrm{d}) \mathrm{x}=$ $0.25,(\mathrm{e}, \mathrm{f}) \mathrm{x}=0.5,(\mathrm{~g}, \mathrm{~h}) \mathrm{x}=0.75$.

Fig. 10. Observed effective magnetic moments $\mu_{\text {eff }}$ for $\operatorname{La}_{2} \operatorname{CoMg}_{x} \operatorname{Ti}_{1-x} \mathrm{O}_{6}(0 \leq x \leq$ 0.6). Expected moments for $\mathrm{HS} \mathrm{Co}^{2+}, \mathrm{Co}^{3+}$ and $\mathrm{Co}^{4+}$ in HS, IS, and LS states are indicated.

Fig. 11 (a) Ti- $K$ and (b) Co- $K$ edge spectra of the selected samples in the $\mathrm{La}_{2} \mathrm{Co}_{1+z}\left(\mathrm{Ti}_{1-\mathrm{x}} \mathrm{Mg}_{\mathrm{x}}\right)_{1-\mathrm{z}} \mathrm{O}_{6}$ series. $\mathrm{x}$ refers to $\mathrm{La}_{2} \mathrm{Co}\left(\mathrm{Ti}_{1-\mathrm{x}} \mathrm{Mg}_{\mathrm{x}}\right) \mathrm{O}_{6}$ and $\mathrm{z}$ refers to $\mathrm{La}_{2} \mathrm{Co}_{1+\mathrm{z}}\left(\mathrm{Ti}_{0.5} \mathrm{Mg}_{0.5}\right)_{1-\mathrm{z}} \mathrm{O}_{6}$ sub-series. Insets: Energy position of the $\mathrm{Co} 4 p$ feature as a function of formal cobalt valence demonstrating the chemical shift. Energy positions were defined by fitting a tip of function of form [Gaussian $\left(A_{G}, E_{0}, W\right)+$ Gaussian $\left.\operatorname{step}\left(\mathrm{A}_{\mathrm{S}}=1.0, \mathrm{E}_{\mathrm{o}}, \mathrm{W}\right)\right]\left(\mathrm{A}=\right.$ amplitude, $\mathrm{E}_{\mathrm{o}}=$ energy position and $\mathrm{W}=$ width $)$. Different samples in the $\mathrm{La}_{2} \mathrm{Co}_{1+\mathrm{z}}\left(\mathrm{Ti}_{0.5} \mathrm{Mg}_{0.5}\right)_{1-\mathrm{z}} \mathrm{O}_{6}$ sub-series, for which the formal oxidation state of $\mathrm{Co}$ is $3+$, are highlighted with colors.

Fig. $12 \mathrm{Ti}-L_{2,3}$ spectra of the selected samples in the $\mathrm{La}_{2} \mathrm{Co}_{1+\mathrm{z}}\left(\mathrm{Ti}_{1-\mathrm{x}} \mathrm{Mg}_{\mathrm{x}}\right)_{1-\mathrm{z}} \mathrm{O}_{6}$ series. Extreme values of the peak-splitting are high-lighted. $x$ refers to $\operatorname{La}_{2} \operatorname{Co}\left(\mathrm{Ti}_{1-\mathrm{x}} \mathrm{Mg}_{\mathrm{x}}\right) \mathrm{O}_{6}$ and $\mathrm{z}$ refers to $\mathrm{La}_{2} \mathrm{Co}_{1+\mathrm{z}}\left(\mathrm{Ti}_{0.5} \mathrm{Mg}_{0.5}\right)_{1-\mathrm{z}} \mathrm{O}_{6}$ sub-series.

Fig.13 (a) Co- $L_{2,3}$ spectra of the selected samples in the $\mathrm{La}_{2} \mathrm{Co}_{1+\mathrm{z}}\left(\mathrm{Ti}_{1-\mathrm{x}} \mathrm{Mg}_{\mathrm{x}}\right)_{1-\mathrm{z}} \mathrm{O}_{6}$ series. $x$ refers to $\mathrm{La}_{2} \mathrm{Co}\left(\mathrm{Ti}_{1-\mathrm{x}} \mathrm{Mg}_{\mathrm{x}}\right) \mathrm{O}_{6}$ and $\mathrm{z}$ refers to $\mathrm{La}_{2} \mathrm{Co}_{1+\mathrm{z}}\left(\mathrm{Ti}_{0.5} \mathrm{Mg}_{0.5}\right)_{1-\mathrm{z}} \mathrm{O}_{6}$ subseries. (b) Shifts of the centers of gravities of the Co- $L_{2}$ and $-L_{3}$ branches and (c) branching ratio as a function of formal oxidation state of Co. Different samples in the 
$\mathrm{La}_{2} \mathrm{Co}_{1+\mathrm{z}}\left(\mathrm{Ti}_{0.5} \mathrm{Mg}_{0.5}\right)_{1-\mathrm{z}} \mathrm{O}_{6}$ sub-series, for which the formal oxidation state of Co is $3+$, are highlighted with colors.

Fig. 14 (a) $\mathrm{O}-K$ spectra of the selected samples in the $\mathrm{La}_{2} \mathrm{Co}_{1+\mathrm{z}}\left(\mathrm{Ti}_{1-\mathrm{x}} \mathrm{Mg}_{\mathrm{x}}\right)_{1-\mathrm{z}} \mathrm{O}_{6}$ system. $\mathrm{x}$ refers to $\mathrm{La}_{2} \mathrm{Co}\left(\mathrm{Ti}_{1-\mathrm{x}} \mathrm{Mg}_{\mathrm{x}}\right) \mathrm{O}_{6}$ and $\mathrm{z}$ refers to $\mathrm{LaCo}_{1+\mathrm{z}}\left(\mathrm{Ti}_{0.5} \mathrm{Mg}_{0.5}\right)_{1-\mathrm{z}} \mathrm{O}_{6}$ sub-series. (Division into hybrid regions, see e.g. [52] ) (b) Peak-fitting scheme for the Co/Ti3d$\mathrm{O} 2 p$ hybrid structure: Two functions $f_{1}$ and $f_{2}$ of $\left[\left(\operatorname{Gaussian}\left(\mathrm{A}_{\mathrm{G}}, \mathrm{E}_{\mathrm{o}}, \mathrm{W}\right)+\right.\right.$ $\left.\left.\tanh \left(\mathrm{A}_{\mathrm{T}}, \mathrm{E}_{\mathrm{o}}, \mathrm{W} / 2\right)\right)\right]$ form were fitted. $\mathrm{A}_{\mathrm{G}}$ and $\mathrm{A}_{\mathrm{T}}$ parameters were iterated so that $\mathrm{A}_{\mathrm{G}}\left(f_{1}\right) / \mathrm{A}_{\mathrm{T}}\left(f_{1}\right)=\mathrm{A}_{\mathrm{G}}\left(f_{1}\right) / \mathrm{A}_{\mathrm{T}}\left(f_{1}\right)$. The energy positions of the $\mathrm{E}$ and $\mathrm{F}$ features, that remained unchanged in all samples without any forced convergence, are also indicated. (c) $(\mathrm{E} /(\mathrm{E}+\mathrm{F})) /(1+\mathrm{z})$ as a function of the formal oxidation state of Co. Different samples in the $\mathrm{LaCo}_{1+\mathrm{z}}\left(\mathrm{Ti}_{0.5} \mathrm{Mg}_{0.5}\right)_{1-\mathrm{z}} \mathrm{O}_{6}$ sub-series, for which the formal oxidation state of $\mathrm{Co}$ is $3+$, are highlighted with colours. 


\section{TABLES}

Table 1. Tabulation of synthesised compounds with nominal valency of $\mathrm{Co}\left(\mathrm{Co}_{\text {val }}\right)$, space group symmetry, unit cell parameters and t-value (calculated using $\mathrm{r}_{\mathrm{Co}^{2+}}=0.745 \AA, \mathrm{r}_{\mathrm{Co}^{3+}}=0.545 \AA, \mathrm{r}_{\mathrm{Co}^{4+}}$ $\left.=0.530 \AA, \mathrm{r}_{\mathrm{Mg} 2+}=0.720 \AA, \mathrm{r}_{\mathrm{Ti}^{4+}}=0.605 \AA\right)$.

\begin{tabular}{|c|c|c|c|c|c|c|c|}
\hline Composition & $\mathrm{Co}_{\text {val }}$ & Symmetry & $a(\AA)$ & $b(\stackrel{a}{)})$ & $c(\AA)$ & $\beta(\AA)$ & $\mathrm{t}$ \\
\hline \multicolumn{8}{|l|}{$\begin{array}{l}\mathrm{La}_{2} \mathrm{Co}\left(\mathrm{Mg}_{x} \mathrm{Ti}_{1-x}\right) \mathrm{O}_{6} \\
\mathrm{z}=0,0 \leq \mathrm{x} \leq 0.9\end{array}$} \\
\hline $\mathrm{La}_{2} \mathrm{CoTiO}_{6}$ & 2.00 & $P 2_{1} / n$ & $5.5622(2)$ & $5.5572(2)$ & $7.8642(2)$ & $89.999(2)$ & 0.941 \\
\hline $\mathrm{La}_{2} \mathrm{CoMg}_{0.1} \mathrm{Ti}_{0.9} \mathrm{O}_{6}$ & 2.20 & $P 2_{1} / n$ & $5.5572(2)$ & $5.5746(2)$ & $7.8581(3)$ & $89.999(3)$ & 0.947 \\
\hline $\mathrm{La}_{2} \mathrm{CoMg}_{0.2} \mathrm{Ti}_{0.8} \mathrm{O}_{6}$ & 2.40 & $P 2_{1} / n$ & $5.5483(2)$ & $5.5536(2)$ & $7.8388(3)$ & $89.999(2)$ & 0.954 \\
\hline $\mathrm{La}_{2} \mathrm{CoMg}_{0.25} \mathrm{Ti}_{0.75} \mathrm{O}_{6}$ & 2.50 & $P 2_{1} / n$ & $5.5350(2)$ & $5.5287(2)$ & $7.8123(5)$ & $89.979(5)$ & 0.957 \\
\hline $\mathrm{La}_{2} \mathrm{CoMg}_{0.3} \mathrm{Ti}_{0.7} \mathrm{O}_{6}$ & 2.60 & Pbnm & $5.5320(7)$ & $5.5211(3)$ & $7.8094(7)$ & & 0.960 \\
\hline $\mathrm{La}_{2} \mathrm{CoMg}_{0.4} \mathrm{Ti}_{0.6} \mathrm{O}_{6}$ & 2.80 & Pbnm & $5.5256(2)$ & $5.4951(2)$ & $7.7805(4)$ & & 0.967 \\
\hline $\mathrm{La}_{2} \mathrm{CoMg}_{0.5} \mathrm{Ti}_{0.5} \mathrm{O}_{6}$ & 3.00 & $R \overline{3} c$ & $5.492(1)$ & & $13.265(4)$ & & 0.974 \\
\hline $\mathrm{La}_{2} \mathrm{CoMg}_{0.6} \mathrm{Ti}_{0.4} \mathrm{O}_{6}{ }^{\mathrm{a}}$ & 3.20 & $R \overline{3} c$ & $5.481(1)$ & & $13.258(3)$ & & 0.972 \\
\hline $\mathrm{La}_{2} \mathrm{CoMg}_{0.7} \mathrm{Ti}_{0.3} \mathrm{O}_{6}^{\mathrm{a}, \mathrm{b}}$ & 3.40 & $R \overline{3} c$ & $5.485(1)$ & & $13.255(2)$ & & 0.970 \\
\hline $\mathrm{La}_{2} \mathrm{CoMg}_{0.75} \mathrm{Ti}_{0.25} \mathrm{O}_{6}^{\mathrm{a}, \mathrm{b}}$ & 3.50 & $R \overline{3} c$ & $5.479(1)$ & & $13.231(2)$ & & 0.969 \\
\hline $\mathrm{La}_{2} \mathrm{CoMg}_{0.8} \mathrm{Ti}_{0.2} \mathrm{O}_{6}{ }^{\mathrm{a}, \mathrm{b}}$ & 3.60 & $R \overline{3} c$ & $5.472(1)$ & & $13.200(2)$ & & 0.968 \\
\hline $\mathrm{La}_{2} \mathrm{CoMg}_{0.9} \mathrm{Ti}_{0.1} \mathrm{O}_{6}^{\mathrm{a}, \mathrm{b}}$ & 3.80 & $R \overline{3} c$ & $5.457(1)$ & & $13.144(2)$ & & 0.966 \\
\hline \multicolumn{8}{|l|}{$\begin{array}{l}\mathrm{La}_{2} \mathrm{Co}_{1+z}(\mathrm{Ti})_{1-z} \mathrm{O}_{6} \\
\mathrm{x}=0,0 \leq \mathrm{z} \leq 0.75\end{array}$} \\
\hline $\mathrm{La}_{2} \mathrm{CoTiO}_{6}$ & 2.00 & $P 2_{1} / n$ & $5.5622(2)$ & $5.5572(2)$ & $7.8642(2)$ & $89.999(2)$ & 0.941 \\
\hline $\mathrm{La}_{2} \mathrm{Co}_{1.2} \mathrm{Ti}_{0.8} \mathrm{O}_{6}$ & 2.33 & $P 2_{1} / n$ & $5.5469(3)$ & $5.5520(3)$ & $7.8569(4)$ & $89.98(2)$ & 0.952 \\
\hline $\mathrm{La}_{2} \mathrm{Co}_{1.4} \mathrm{Ti}_{0.6} \mathrm{O}_{6}$ & 2.57 & Pbnm & $5.5237(2)$ & $5.4416(2)$ & $7.7789(3)$ & & 0.965 \\
\hline $\mathrm{La}_{2} \mathrm{Co}_{1.6} \mathrm{Ti}_{0.4} \mathrm{O}_{6}$ & 2.75 & $R \overline{3} c$ & $5.4900(2)$ & & $13.225(1)$ & & 0.977 \\
\hline \multicolumn{8}{|l|}{$\begin{array}{l}\mathrm{La}_{2} \mathrm{Co}_{1+z}\left(\mathrm{Mg}_{0.25} \mathrm{Ti}_{0.75}\right)_{1-z} \mathrm{O}_{6} \\
\mathrm{x}=\mathbf{0 . 2 5 , 0} \leq \mathrm{z} \leq \mathbf{0 . 7 5}\end{array}$} \\
\hline $\mathrm{La}_{2} \mathrm{CoMg}_{0.25} \mathrm{Ti}_{0.75} \mathrm{O}_{6}$ & 2.50 & $P 2_{1} / n$ & $5.5350(2)$ & $5.5287(2)$ & $7.8123(5)$ & $89.979(5)$ & 0.957 \\
\hline $\mathrm{La}_{2} \mathrm{Co}_{1.2}\left(\mathrm{Mg}_{0.25} \mathrm{Ti}_{0.75}\right)_{0.8} \mathrm{O}_{6}$ & 2.67 & Pbnm & $5.5236(3)$ & $5.4927(3)$ & $7.7786(5)$ & & 0.966 \\
\hline $\mathrm{La}_{2} \mathrm{Co}_{1.4}\left(\mathrm{Mg}_{0.25} \mathrm{Ti}_{0.75}\right)_{0.6} \mathrm{O}_{6}{ }^{\mathrm{a}}$ & 2.79 & $R \overline{3} c$ & $5.503(1)$ & & $13.257(2)$ & & 0.975 \\
\hline $\mathrm{La}_{2} \mathrm{Co}_{1.6}\left(\mathrm{Mg}_{0.25} \mathrm{Ti}_{0.75}\right)_{0.4} \mathrm{O}_{6}$ & 2.88 & $R \overline{3} c$ & $5.4744(3)$ & & $13.193(1)$ & & 0.984 \\
\hline \multicolumn{8}{|l|}{$\begin{array}{l}\mathrm{La}_{2} \mathrm{Co}_{1+z}\left(\mathrm{Mg}_{0.50} \mathrm{Ti}_{0.50}\right)_{1-z} \mathrm{O}_{6} \\
\mathrm{x}=\mathbf{0 . 5 0 , 0} \leq \mathrm{z} \leq 0.75\end{array}$} \\
\hline $\mathrm{La}_{2} \mathrm{CoMg}_{0.5} \mathrm{Ti}_{0.5} \mathrm{O}_{6}$ & 3.00 & $R \overline{3} c$ & $5.492(1)$ & & $13.265(4)$ & & 0.974 \\
\hline $\mathrm{La}_{2} \mathrm{Co}_{1.2}\left(\mathrm{Mg}_{0.5} \mathrm{Ti}_{0.5}\right)_{0.8} \mathrm{O}_{6}{ }^{\mathrm{a}}$ & 3.00 & $R \overline{3} c$ & $5.480(1)$ & & $13.226(2)$ & & 0.980 \\
\hline $\mathrm{La}_{2} \mathrm{Co}_{1.4}\left(\mathrm{Mg}_{0.5} \mathrm{Ti}_{0.5}\right)_{0.6} \mathrm{O}_{6}$ & 3.00 & $R \overline{3} c$ & $5.4674(5)$ & & $13.186(1)$ & & 0.985 \\
\hline $\mathrm{La}_{2} \mathrm{Co}_{1.6}\left(\mathrm{Mg}_{0.5} \mathrm{Ti}_{0.5}\right)_{0.4} \mathrm{O}_{6}$ & 3.00 & $R \overline{3} c$ & $5.4576(5)$ & & $13.154(1)$ & & 0.991 \\
\hline \multicolumn{8}{|l|}{$\begin{array}{l}\mathrm{La}_{2} \mathrm{Co}_{1+z}\left(\mathrm{Mg}_{0.75} \mathrm{Ti}_{0.25}\right)_{1-z} \mathrm{O}_{6} \\
\mathrm{x}=\mathbf{0 . 7 5 , 0}, \mathrm{z} \leq \mathbf{z . 7 5}\end{array}$} \\
\hline $\mathrm{La}_{2} \mathrm{CoMg}_{0.75} \mathrm{Ti}_{0.75} \mathrm{O}_{6}$ & 3.50 & $R \overline{3} c$ & $5.479(1)$ & & $13.231(2)$ & & 0.969 \\
\hline $\mathrm{La}_{2} \mathrm{Co}_{1.2}\left(\mathrm{Mg}_{0.75} \mathrm{Ti}_{0.25}\right)_{0.8} \mathrm{O}_{6}{ }^{\mathrm{a}}$ & 3.33 & $R \overline{3} c$ & $5.470(1)$ & & $13.223(2)$ & & 0.955 \\
\hline $\mathrm{La}_{2} \mathrm{Co}_{1.4}\left(\mathrm{Mg}_{0.75} \mathrm{Ti}_{0.2 .5}\right)_{0.6} \mathrm{O}_{6}$ & 3.21 & $R \overline{3} c$ & $5.5609(7)$ & & $13.154(2)$ & & 0.967 \\
\hline $\mathrm{La}_{2} \mathrm{Co}_{1.6}\left(\mathrm{Mg}_{0.75} \mathrm{Ti}_{0.2 .5}\right)_{0.4} \mathrm{O}_{6}$ & 3.13 & $R \overline{3} c$ & $5.4546(8)$ & & $13.156(2)$ & & 0.979 \\
\hline
\end{tabular}

${ }^{\mathrm{a}}$ Contains also a cubic $\operatorname{Pm} \overline{\mathrm{3}} \mathrm{m}$ perovskite phase; ${ }^{\mathrm{b}}$ Contains secondary phases. 
Table 2. Crystallographic and refinement data for phases with $P 2{ }_{1} / n$ symmetry from XRPD data.

\begin{tabular}{|c|c|c|c|}
\hline $\mathrm{a} / \AA$ & $\begin{array}{l}\mathrm{La}_{2} \mathrm{COTiO}_{6} \\
5.5622(2)\end{array}$ & $\begin{array}{r}\mathrm{La}_{2} \mathrm{CoMg}_{0.1} \mathrm{Ti}_{0.9} \mathrm{O}_{6} \\
5.5572(2)\end{array}$ & $\begin{array}{r}\mathrm{La}_{2} \mathrm{COMg}_{0.2} \mathrm{Ti}_{0.8} \mathrm{O}_{6} \\
5.5483(2)\end{array}$ \\
\hline $\mathrm{b} / \AA$ & $5.5575(2)$ & $5.5746(2)$ & $5.5536(2)$ \\
\hline$c / \AA$ & $7.8642(2)$ & $7.8581(3)$ & $7.8388(3)$ \\
\hline$\beta /{ }^{\circ}$ & $90.000(2)$ & $89.999(3)$ & $89.999(2)$ \\
\hline La & $4 e(x, y, z)$ & & \\
\hline$x$ & $-0.0041(2)$ & $-0.0066(1)$ & $-0.0041(1)$ \\
\hline $\mathrm{y}$ & $-0.0312(2)$ & $-0.0319(1)$ & $-0.0298(1)$ \\
\hline z & $0.2457(1)$ & $0.2491(3)$ & $0.2473(1)$ \\
\hline $\mathrm{Col} / \mathrm{Mg} / \mathrm{Ti}$ & $2 \mathrm{~d} \quad(1 / 2,0,0)$ & & \\
\hline $\operatorname{sof}(\mathrm{Co})$ & $0.99(1)$ & $0.99(1)$ & $0.94(2$ \\
\hline $\mathrm{Co} 2 / \mathrm{Mg} / \mathrm{Ti}$ & $2 \mathrm{c} \quad(0,1 / 2,0)$ & & \\
\hline $\operatorname{sof}(\mathrm{CO})$ & $0.83(1)$ & $0.79(1)$ & $0.80(1$ \\
\hline 01 & $4 e \quad(x, y, z)$ & & \\
\hline $\mathrm{x}$ & $0.3005(11)$ & 0.2901 (11) & $0.2903(16$ \\
\hline $\mathrm{y}$ & $0.2910(8)$ & $0.2809(20)$ & $0.2881(18$ \\
\hline $\mathrm{z}$ & $-0.0279(7)$ & $-0.0351(32)$ & $-0.0300(12$ \\
\hline 02 & $4 e \quad(x, y, z)$ & & \\
\hline $\mathrm{x}$ & $0.2279(10)$ & 0.2138 (11) & $0.2197(14$ \\
\hline y & $0.7720(8)$ & $0.7823(19)$ & $0.7803(17$ \\
\hline $\mathrm{z}$ & $-0.0464(6)$ & $-0.0367(32)$ & $-0.0379(11$ \\
\hline 03 & $4 e \quad(x, y, z)$ & & \\
\hline $\mathrm{x}$ & $0.4304(6)$ & $0.4281(4)$ & $0.4289(6$ \\
\hline Y & $0.0135(2)$ & $0.0112(1)$ & $0.0085(1$ \\
\hline $\mathrm{z}$ & $0.2482(16)$ & $0.2478(17)$ & $0.2502(20$ \\
\hline $\mathrm{R}_{\mathrm{F}}$ & 4.3 & 5.4 & 4 \\
\hline $\mathrm{R}_{\mathrm{p}}$ & 16.6 & 14.6 & 13. \\
\hline$\chi^{2}$ & 0.71 & 0.80 & 0.7 \\
\hline
\end{tabular}


Table 3. Crystallographic and refinement data for phases with Pbnm symmetry from XRPD data.

\begin{tabular}{|c|c|c|}
\hline & $\mathrm{La}_{2} \mathrm{CoMg}_{0.3} \mathrm{Ti}_{0.7} \mathrm{O}_{6}$ & $\mathrm{La}_{2} \mathrm{CoMg}_{0.4} \mathrm{Ti}_{0.6} \mathrm{O}_{6}$ \\
\hline $\mathrm{a} / \AA$ & $5.5320(7)$ & $5.5256(2)$ \\
\hline $\mathrm{b} / \AA$ & $5.5211(3)$ & $5.4951(2)$ \\
\hline $\mathrm{C} / \AA$ & $7.8094(7)$ & $7.7805(4)$ \\
\hline La & $4 \mathrm{C}(\mathrm{x}, \mathrm{y}, 1 / 4)$ & \\
\hline$x$ & $-0.0074(5)$ & $-0.0042(7)$ \\
\hline$y$ & $-0.0244(2)$ & $-0.0213(2)$ \\
\hline $\mathrm{Co} / \mathrm{Mg} / \mathrm{Ti}$ & $4 \mathrm{~b}(0,1 / 2,0)$ & \\
\hline $\mathrm{sof}(\mathrm{Co})$ & $0.900(4)$ & $0.874(4)$ \\
\hline 01 & $8 d(x, y, z)$ & \\
\hline$x$ & $0.2830(3)$ & $0.2878(2)$ \\
\hline Y & $0.2886(3)$ & $0.2942(2)$ \\
\hline $\bar{z}$ & $-0.0279(2)$ & $-0.0265(2)$ \\
\hline $\mathrm{O} 2$ & $4 c(x, y, 1 / 4)$ & \\
\hline$x$ & $0.4312(4)$ & $0.4465(3)$ \\
\hline $\mathrm{y}$ & $0.0116(2)$ & $0.0040(2)$ \\
\hline $\mathrm{R}_{\mathrm{F}}$ & 2.7 & 2.6 \\
\hline$R_{p}$ & 15.0 & 16.3 \\
\hline$\chi^{2}$ & 0.75 & 0.96 \\
\hline & & \\
\hline
\end{tabular}


Table 4. Crystallographic and refinement data for phases with $R \overline{3} c$ symmetry from XRPD data.

\begin{tabular}{|c|c|c|c|c|c|}
\hline & $\mathrm{La}_{2} \mathrm{CoMg}_{0.5} \mathrm{Ti}_{0.5} \mathrm{O}_{6}$ & $\mathrm{La}_{2} \mathrm{COMg}_{0.6} \mathrm{Ti}_{0.4} \mathrm{O}_{6}$ & $\mathrm{La}_{2} \mathrm{Co}_{1.2} \mathrm{Mg}_{0.4} \mathrm{Ti}_{0.4} \mathrm{O}_{6}$ & $\mathrm{La}_{2} \mathrm{Co}_{1.4} \mathrm{Mg}_{0.3} \mathrm{Ti}_{0.3 \mathrm{O}_{6}}$ & $\mathrm{La}_{2} \mathrm{Co}_{1.6} \mathrm{Mg}_{0.2} \mathrm{Ti}_{0.2} \mathrm{O}_{6}$ \\
\hline $\mathrm{a} / \AA$ & $5.492(1)$ & $5.481(1)$ & $5.480(1)$ & $5.4674(5)$ & $5.4576(5)$ \\
\hline $\mathrm{C} / \AA$ & $13.265(4)$ & $13.258(3)$ & $13.226(2)$ & $13.186(1)$ & $13.154(1)$ \\
\hline $\mathrm{La}$ & $6 a(0,0,1 / 4)$ & & & & \\
\hline $\mathrm{Co} / \mathrm{Mg} / \mathrm{Ti}$ & $6 \mathrm{~b}(0,0,0)$ & & & & \\
\hline sof $(\mathrm{Co})$ & $0.863(5)$ & $0.863(5)$ & $0.835(6)$ & $0.933(3)$ & $0.950(4)$ \\
\hline 0 & $18 e(x, 0,1 / 4)$ & & & & \\
\hline $\mathrm{x}$ & $0.5620(15)$ & $0.5542(12)$ & $0.5535(13)$ & $0.5480(11)$ & $0.5463(14)$ \\
\hline $\mathrm{R}_{\mathrm{F}}$ & 5.6 & 2.3 & 3.2 & 2.8 & 4.7 \\
\hline$R_{p}$ & 18.8 & 18.1 & 18.8 & 17.0 & 26.2 \\
\hline$\chi^{2}$ & 1.11 & 1.08 & 1.21 & 1.17 & 0.96 \\
\hline
\end{tabular}


Table 5. Selected inter-atomic distances $(\AA)$ and angles $\left({ }^{\circ}\right)$ for phases with $P 2{ }_{1} / n$ symmetry from XRPD data.

\begin{tabular}{|c|c|c|c|}
\hline & $\mathrm{La}_{2} \mathrm{CoTiO}_{6}$ & $\mathrm{La}_{2} \mathrm{Mg}_{0.1} \mathrm{Ti}_{0.9} \mathrm{O}_{6}$ & $\mathrm{La}_{2} \mathrm{Mg}_{0.2} \mathrm{Ti}_{0.8} \mathrm{O}_{6}$ \\
\hline $\begin{array}{l}\mathrm{L} a-\mathrm{O} 1 \\
\mathrm{La}-\mathrm{O} 1 \\
\mathrm{La}-\mathrm{O} 1 \\
\mathrm{~L} a-\mathrm{O} 2 \\
\mathrm{La}-\mathrm{O} 2 \\
\mathrm{La}-\mathrm{O} 2 \\
\mathrm{~L} a-\mathrm{O} 3 \\
\mathrm{La}-\mathrm{O} 3 \\
\mathrm{La}-\mathrm{O} 3 \\
\mathrm{~L} a-\mathrm{O} 3 \\
\mathrm{~B} 1-\mathrm{O} 1 \\
\mathrm{~B} 1-\mathrm{O} 2 \\
\mathrm{~B} 1-\mathrm{O} 3 \\
\mathrm{~B} 2-\mathrm{O} 1 \\
\mathrm{~B} 2-\mathrm{O} 2 \\
\mathrm{~B} 2-\mathrm{O} 3\end{array}$ & 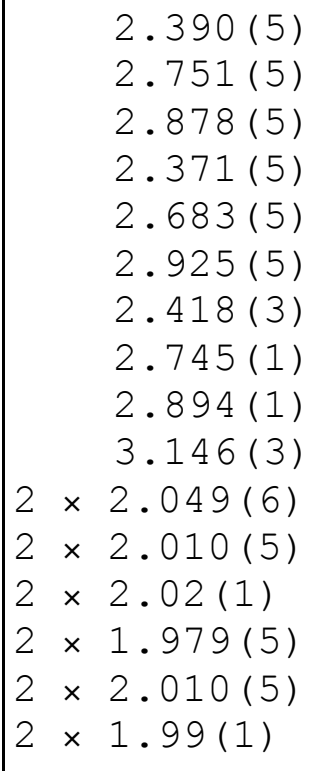 & $\begin{array}{l}2.38(2) \\
2.79(2) \\
2.83(2) \\
2.36(2) \\
2.78(2) \\
2.83(3) \\
2.417(2) \\
2.760(1) \\
2.883(1) \\
3.142(2) \\
2.04(1) \\
1.99(1) \\
2.02(1) \\
1.97(1) \\
2.02(1) \\
1.99(1)\end{array}$ & $\begin{array}{l}2.39(1) \\
2.78(1) \\
2.83(1) \\
2.37(1) \\
2.76(1) \\
2.83(1) \\
2.403(3) \\
2.761(1) \\
2.855(1) \\
3.146(3) \\
2.006(9) \\
2.002(9) \\
1.997(15) \\
1.995(10) \\
1.996(8) \\
2.002(15)\end{array}$ \\
\hline $\begin{array}{l}\mathrm{B} 1-\mathrm{O} 1-\mathrm{B} 2 \\
\mathrm{~B} 1-\mathrm{O} 2-\mathrm{B} 2 \\
\mathrm{~B} 1-\mathrm{O} 3-\mathrm{B} 2\end{array}$ & $\begin{array}{l}155.8(2) \\
156.8(2) \\
157.3(5)\end{array}$ & $\begin{array}{l}157.5(4) \\
157.2(4) \\
156.7(5)\end{array}$ & $\begin{array}{l}157.6(4) \\
158.0(4) \\
157.1(6)\end{array}$ \\
\hline
\end{tabular}


Table 6. Selected inter-atomic distances $(\AA)$ and angles $\left({ }^{\circ}\right)$ for phases with $\mathrm{Pbnm}$ symmetry from XRPD data.

\begin{tabular}{|l|c|l|}
\hline & $\mathrm{La}_{2} \mathrm{Mg}_{0.3} \mathrm{Ti}_{0.7} \mathrm{O}_{6}$ & $\mathrm{La}_{2} \mathrm{Mg}_{0.4} \mathrm{Ti}_{0.6} \mathrm{O}_{6}$ \\
\hline $\mathrm{La}-\mathrm{O} 1$ & $2.445(4)$ & $2.494(4)$ \\
$\mathrm{La}-\mathrm{O} 1$ & $2.595(2)$ & $2.628(2)$ \\
$\mathrm{La}-\mathrm{O} 1$ & $2.988(2)$ & $2.904(2)$ \\
$\mathrm{La}-01$ & $3.101(4)$ & $3.038(4)$ \\
$\mathrm{La}-\mathrm{O} 2$ & $2 \times 2.459(2)$ & $2.429(2)$ \\
$\mathrm{La}-\mathrm{O} 2$ & $2 \times 2.705(2)$ & $2.662(2)$ \\
$\mathrm{La}-\mathrm{O} 2$ & $2 \times 2.731(2)$ & $2.780(3)$ \\
$\mathrm{B}-\mathrm{O} 1$ & $2 \times 1.9880(4)$ & $1.9676(3)$ \\
$\mathrm{B}-\mathrm{O} 2$ & $2 \times 2.007(2)$ & $2.008(1)$ \\
$\mathrm{B}-\mathrm{O} 3$ & $2 \times 1.965(2)$ & $1.962(1)$ \\
\hline $\mathrm{B}-01-\mathrm{B}$ & $159.4(1)$ & $162.7(1)$ \\
$\mathrm{B}-02-\mathrm{B}$ & $158.3(1)$ & $157.9(1)$ \\
\hline
\end{tabular}


Table 7. Selected inter-atomic distances and angles for phases with $R \overline{3} c$ symmetry from XRPD data.

\begin{tabular}{|l|l|l|l|l|l|}
\hline & $\mathrm{La}_{2} \mathrm{CoMg}_{0.5} \mathrm{Ti}_{0.5} \mathrm{O}_{6}$ & $\begin{array}{l}\mathrm{La}_{2} \mathrm{COMg}_{0.6} \mathrm{Ti}_{0.4} \\
\mathrm{O}_{6}\end{array}$ & $\begin{array}{l}\mathrm{La}_{2} \mathrm{CO}_{1.2} \mathrm{Mg}_{0.4} \mathrm{Ti}_{0} . \\
\mathrm{O}_{6}\end{array}$ & $\begin{array}{l}\mathrm{La}_{2} \mathrm{CO}_{1 .} \mathrm{Mg}_{0.5} \mathrm{Ti}_{0} . \\
5 \mathrm{O}_{6}\end{array}$ & $\begin{array}{l}\mathrm{La}_{2} \mathrm{CO}_{1 .} \mathrm{Mg}_{0.5} \mathrm{Ti}_{0} . \\
5 \mathrm{O}_{6}\end{array}$ \\
\hline $\mathrm{La}-\mathrm{O}$ & $3 \times 2.406(8)$ & $2.443(7)$ & $2.446(7)$ & $2.471(6)$ & $2.476(4)$ \\
$\mathrm{La}-\mathrm{O}$ & $6 \times 3.087(4)$ & $3.038(3)$ & $3.033(3)$ & $2.996(3)$ & $2.981(4)$ \\
$\mathrm{La}-0$ & $3 \times 2.742(4)$ & $2.734(3)$ & $2.729(4)$ & $2.718(3)$ & $2.711(4)$ \\
$\mathrm{B}-\mathrm{O}$ & $6 \times 1.963(6)$ & $1.952(5)$ & $1.950(5)$ & $1.941(5)$ & $1.936(5)$ \\
\hline $\mathrm{B}-\mathrm{O}-\mathrm{B}$ & $160.02(6)$ & $162.50(3)$ & $162.68(4)$ & $164.46(4)$ & $165.00(4)$ \\
\hline
\end{tabular}




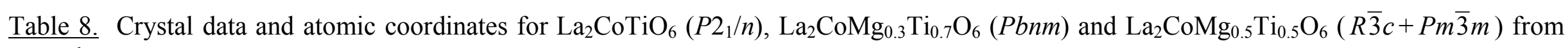
NPD data

\begin{tabular}{|c|c|c|c|c|c|c|}
\hline \multicolumn{2}{|l|}{$P 2_{1} / n$} & $\mathrm{a} / \AA$ & $\mathrm{b} / \AA$ & $\mathrm{C} / \AA$ & $\beta /^{\circ}$ & \\
\hline \multicolumn{2}{|c|}{ Unit cell } & $5.5628(1)$ & $5.57271(9)$ & $7.8630(1)$ & $90.03(1)$ & \\
\hline Atom & pos & $\mathrm{x}$ & $\mathrm{x}$ & $\mathrm{y}$ & $\mathrm{U} \times 10^{3}$ & sof \\
\hline La & $4 e$ & $-0.0053(2)$ & $0.03085(9)$ & $0.2498(5)$ & $0.70(1)$ & 1 \\
\hline Col/Til & $2 \mathrm{~b}$ & 0.5 & 0 & 0.5 & $1.4(1)$ & $0.925(5) / 0.075(5)$ \\
\hline $\mathrm{Co} 2 / \mathrm{Ti} 2$ & $2 d$ & 0.5 & 0 & 0 & $0.65(7)$ & $0.075(2) / 0.925(2)$ \\
\hline $\mathrm{O} 1$ & $4 \mathrm{e}$ & $0.2904(6)$ & $0.7201(6)$ & $-0.0413(1)$ & $0.69(7)$ & 1 \\
\hline 02 & $4 e$ & $0.2230(6)$ & $0.2092(6)$ & $-0.0370(4)$ & $0.74(7)$ & 1 \\
\hline 03 & $4 \mathrm{e}$ & $0.4274(2)$ & $0.9858(2)$ & $0.2430(3)$ & $0.48(2)$ & 1 \\
\hline
\end{tabular}

Comments: $\mathrm{R}_{\mathrm{F}}($ bank $6,5,4)=1.86,1.04,1.00 \%, \chi^{2}=2.04$ for all banks with 82 variables refined.

\section{$\mathrm{La}_{2} \mathrm{CoMg}_{0.3} \mathrm{Ti}_{0.7} \mathrm{O}_{6}$}

\begin{tabular}{|l|l|l|l|l|l|l|}
\hline \multicolumn{2}{|l|}{ Pbnm } & $\mathrm{a} / \AA$ & $\mathrm{b} / \AA$ & $\mathrm{c} / \AA$ & & \\
\hline Unit cell & $5.5345(2)$ & $5.5158(1)$ & $7.8036(2)$ & & $\mathrm{Z}$ \\
\hline Atom & $\mathrm{pos}$ & $\mathrm{x}$ & $\mathrm{y}$ & $\mathrm{Z}$ & $10^{3}$ & $\mathrm{sof}$ \\
\hline $\mathrm{La}$ & $4 \mathrm{c}$ & $-0.0055(2)$ & $0.4749(1)$ & 0.25 & $0.73(1)$ & 1 \\
\hline $\mathrm{Co} / \mathrm{Mg} / \mathrm{Ti}$ & $4 \mathrm{a}$ & 0.0 & 0 & 0 & $0.1(4)$ & $0.5 / 0.15 / 0.35$ \\
\hline $\mathrm{O} 1$ & $4 \mathrm{c}$ & $0.0692(2)$ & $0.0080(2)$ & 0.25 & $0.60(2)$ & 1 \\
\hline $\mathrm{O} 2$ & $8 \mathrm{~d}$ & $0.2207(1)$ & $0.2782(1)$ & $-0.0353(1)$ & $0.78(1)$ & 1 \\
\hline
\end{tabular}

Comments: $\mathrm{R}_{\mathrm{F}}($ Bank $6,5,4)=2.39,1.48,1.22 \%, \chi^{2}$ for all banks $=2.02$, with 74 variables refined. 
$\mathrm{La}_{2} \mathrm{CoMg}_{0.5} \mathrm{Ti}_{0.5} \mathrm{O}_{6}$

\begin{tabular}{|c|c|c|c|c|c|c|}
\hline \multicolumn{2}{|l|}{$R \overline{3} c$} & $\mathrm{a} / \AA$ & $c / \AA$ & & & \\
\hline \multicolumn{2}{|l|}{ Unit cell } & $5.4992(3)$ & $13.278(6)$ & & & \\
\hline Atom & pos & $x$ & $\mathrm{y}$ & z & $\mathrm{U} \times 10^{3}$ & sof \\
\hline La & $6 a$ & 0 & 0 & 0.25 & $1.47(6)$ & 1 \\
\hline $\mathrm{Co} / \mathrm{Mg} / \mathrm{Ti}$ & $6 \mathrm{~b}$ & 0.5 & 0 & 0 & $0.8(2)$ & $0.526(4) / 0.276(4) / 0.198(8)$ \\
\hline O & $18 \mathrm{e}$ & $0.5600(3)$ & 0 & 0.25 & $0.44(3)$ & 1 \\
\hline \multicolumn{7}{|l|}{ Pm3m } \\
\hline \multicolumn{2}{|l|}{ Unit cell } & $3.882(2)$ & & & & \\
\hline Atom & pos & $\mathrm{x}$ & $\mathrm{y}$ & z & $\mathrm{U} \times 10^{3}$ & sof \\
\hline La & $1 \mathrm{~b}$ & 0.5 & 0.5 & 0.5 & $2.74(21)$ & 1 \\
\hline $\mathrm{Co} / \mathrm{Mg} / \mathrm{Ti}$ & $1 \mathrm{a}$ & 0 & 0 & 0 & $-2.6(5)$ & $0.419(4) / 0.169(4) / 0.411(8)$ \\
\hline O & $3 d$ & 0.5 & 0 & 0 & $3.4(1)$ & 1 \\
\hline
\end{tabular}

Comments: $R \overline{3} c: \mathrm{R}_{\mathrm{F}}\left(\right.$ Bank 6, 5, 4) $=4.77,3.40,2.73 \%, P m 3 m:-\mathrm{R}_{\mathrm{F}}\left(\right.$ Bank 6, 5, 4) $=4.75,1.79,2.08 \% . \chi^{2}$ for all banks $=10.37$, with 7 variables refined. 
Table 9. Selected inter-atomic distances $(\AA)$ and angles $\left({ }^{\circ}\right)$ for $\mathrm{La}_{2} \mathrm{CoTiO}_{6}\left(P 2_{1} / n\right)$, $\mathrm{La}_{2} \mathrm{CoMg}_{0.3} \mathrm{Ti}_{0.7} \mathrm{O}_{6}(P b n m)$ and $\mathrm{La}_{2} \mathrm{CoMg}_{0.5} \mathrm{Ti}_{0.5} \mathrm{O}_{6}(R \overline{3} c)$ from NPD data.

\begin{tabular}{|c|c|c|c|c|c|}
\hline \multicolumn{2}{|c|}{$\mathrm{La}_{2} \mathrm{CoTiO}_{6}$} & \multicolumn{2}{|c|}{$\mathrm{La}_{2} \mathrm{CoMg}_{0.3} \mathrm{Ti}_{0.7} \mathrm{O}_{6}$} & \multicolumn{2}{|c|}{$\mathrm{La}_{2} \mathrm{CoMg}_{0.5} \mathrm{Ti}_{0.5} \mathrm{O}_{6}$} \\
\hline $\begin{array}{l}\mathrm{La}-\mathrm{O} 1 \\
\mathrm{La}-\mathrm{O} 1 \\
\mathrm{La}-\mathrm{O} 1 \\
\mathrm{La}-\mathrm{O} 2 \\
\mathrm{La}-\mathrm{O} 2 \\
\mathrm{La}-\mathrm{O} 2 \\
\mathrm{La}-\mathrm{O} 3 \\
\mathrm{La}-\mathrm{O} 3 \\
\mathrm{La}-\mathrm{O} 3 \\
\mathrm{La}-\mathrm{O} 3 \\
\mathrm{~B} 1-\mathrm{O} 1 \\
\mathrm{~B} 1-\mathrm{O} 2 \\
\mathrm{~B} 1-\mathrm{O} 3 \\
\mathrm{~B} 2-\mathrm{O} 1 \\
\mathrm{~B} 2-\mathrm{O} 2 \\
\mathrm{~B} 2-\mathrm{O} 3\end{array}$ & 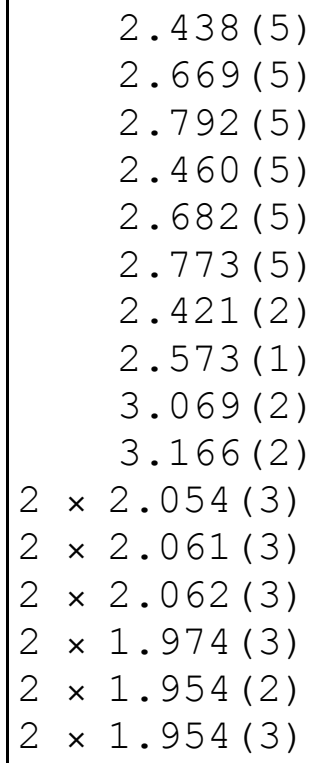 & $\begin{array}{l}\mathrm{La}-\mathrm{O} 1 \\
\mathrm{La}-\mathrm{O} 1 \\
\mathrm{La}-\mathrm{O} 1 \\
\mathrm{La}-\mathrm{O} 1 \\
\mathrm{La}-\mathrm{O} 2 \\
\mathrm{La}-\mathrm{O} 2 \\
\mathrm{La}-\mathrm{O} 2 \\
\mathrm{~B}-\mathrm{O} 1 \\
\mathrm{~B}-\mathrm{O} 2 \\
\mathrm{~B}-\mathrm{O} 2\end{array}$ & $\begin{aligned} & 2.422(1) \\
& 2.609(1) \\
& 2.969(1) \\
& \\
& 3.125(1) \\
2 \times & 2.466(1) \\
2 \times & 2.656(1) \\
2 \times & 2.775(1) \\
2 \times & 1.9886(2) \\
2 \times & 1.981(1) \\
2 \times & 1.991(1)\end{aligned}$ & $\begin{array}{r}\mathrm{La}-0 \\
\mathrm{La}-0 \\
\mathrm{La}-0 \\
\mathrm{~B}-0\end{array}$ & $\begin{array}{l}3 \times 2.419(2) \\
6 \times 2.744(1) \\
3 \times 3.080(2) \\
6 \times 1.963(7)\end{array}$ \\
\hline $\begin{array}{l}\mathrm{B} 1-\mathrm{O} 1-\mathrm{B} 2 \\
\mathrm{~B} 1-\mathrm{O} 2-\mathrm{B} 2 \\
\mathrm{~B} 1-\mathrm{O} 3-\mathrm{B} 2\end{array}$ & $\begin{array}{l}155.5(2)^{\circ} \\
157.3(2)^{\circ} \\
156.3(1)^{\circ}\end{array}$ & $\begin{array}{l}\mathrm{B}-\mathrm{O} 1-\mathrm{B} \\
\mathrm{B}-\mathrm{O} 2-\mathrm{B}\end{array}$ & $\begin{array}{l}157.66(6)^{\circ} \\
159.37(3)^{\circ}\end{array}$ & $B-O-B$ & $160.6(9)^{\circ}$ \\
\hline
\end{tabular}




\section{Figure captions.}

Fig. 1. Illustration of the double perovskite $P 2_{1} / n$ symmetry structure of $\mathrm{La}_{2} \mathrm{CoTiO}_{6}$ with alternating $\mathrm{Co}^{2+}$ (green) and $\mathrm{Ti}^{4+}$ (orange) octahedra.

Fig. 2. Compositional triangle with corners $\mathrm{La}_{2} \mathrm{CoTiO}_{6}-\mathrm{La}_{2} \mathrm{CoMgO}_{6}-\mathrm{LaCoO}_{3}$, showing prepared compositions and symmetries of the observed perovskite-type structures.

Fig. 3. Symmetry distinguishing SAED patterns for: (a) Monoclinic $P 2_{1} / n \mathrm{La}_{2} \mathrm{CoMg}_{0.2} \mathrm{Ti}_{0.8} \mathrm{O}_{6}$ along $[100]_{\text {mon }}=[110]_{\mathrm{p}}$, with no systematic absences revealed due to the presence of weak superstructure reflections (some are marked with arrows). (The expected reflection condition $00 l ; l=2 n$ is not fulfilled due to double diffraction) (b) Orthorhombic Pbnm $\mathrm{La}_{2} \mathrm{CoMg}_{0.3} \mathrm{Ti}_{0.7} \mathrm{O}_{6}$ along $[100]_{\text {ort }}=[110]_{\mathrm{p}}$, with reflection conditions $0 k l ; k=2 n$. The doubling of the perovskite caxis $\left(c=2 c_{p}\right)$ gives rise to weak superstructure reflections (some are marked with arrows). (The reflection condition $00 l ; l=2 n$ is not fulfilled due to double diffraction) (c) rhombohedral, $R \overline{3} c \quad \mathrm{La}_{2} \mathrm{CoMg}_{0.4} \mathrm{Ti}_{0.6} \mathrm{O}_{6}$ along $[110]_{\text {rho }}=[110]_{\mathrm{p}}$, where no superstructure reflections are present. The contrast has been enhanced in order to easier visualise the weaker spots.

Fig. 4. Selected observed (small circles) and calculated (full lines) XRPD patterns for compositions along the lines $\mathrm{La}_{2} \mathrm{Co}\left(\mathrm{Mg}_{x} \mathrm{Ti}_{1-x}\right) \mathrm{O}_{6}$ and $\mathrm{La}_{2} \mathrm{Co}_{1+z}\left(\mathrm{Mg}_{0.5} \mathrm{Ti}_{0.5}\right)_{1-z} \mathrm{O}_{6}$. Positions of reflections from the cubic $P m \overline{3} m$ phases are indicated by asterisks.

Fig. 5. Perovskite sub-cell volume (a) as a function of $x$ in $\mathrm{La}_{2} \mathrm{Co}\left(\mathrm{Mg}_{x} \mathrm{Ti}_{1-x}\right) \mathrm{O}_{6}$ and (b) versus $z$ in $\mathrm{La}_{2} \mathrm{Co}_{1+z}\left(\mathrm{Mg}_{x} \mathrm{Ti}_{1-x}\right)_{1-z} \mathrm{O}_{6}$ for $\mathrm{x}=0.0,0.25,0.50,0.75$.

Fig. 6. Observed compositional dependence of the average octahedral B - O inter-atomic distances as a function of $x$ in $\mathrm{La}_{2} \mathrm{Co}\left(\mathrm{Mg}_{x} \mathrm{Ti}_{1-x}\right) \mathrm{O}_{6}$ and $z$ in $\mathrm{La}_{2} \mathrm{Co}_{1+z}\left(\mathrm{Mg}_{0.5} \mathrm{Ti}_{0.5}\right)_{1-z} \mathrm{O}_{6}$. The values for $x=0.0,0.3$ and 0.5 are from NPD data. The lines are indicated for theoretical estimates of B-O variation for HS (upper line) LS (lower line) using the Shannon ionic radii ${ }^{22}$ and an estimated oxygen radii of $1.342 \AA$.

Fig. 7. Observed (crosses), calculated (line) and difference (bottom) time-of-flight NPD patterns for (a) monoclinic $P 2_{1} / n \mathrm{La}_{2} \mathrm{CoTiO}_{6}$, (b) orthorhombic Pbnm $\mathrm{La}_{2} \mathrm{Co}\left(\mathrm{Mg}_{0.3} \mathrm{Ti}_{0.7}\right)$, (c) rhombohedral $R \overline{3} c+$ cubic $P m \overline{3} m \mathrm{La}_{2} \mathrm{Co}\left(\mathrm{Mg}_{0.5} \mathrm{Ti}_{0.5}\right) \mathrm{O}_{3}$. 
Fig. 8. Variation of (a) $\chi_{m}\left(\right.$ emu/mole*Oe), (b) $1 / \chi_{m}\left(\right.$ Oe*mole/emu) )and (c) $\mu_{\text {eff }}$ (effective Bohr magnetons) with temperature for the series $\mathrm{La}_{2} \mathrm{CoMg}_{\mathrm{x}} \mathrm{Ti}_{1-\mathrm{x}} \mathrm{O}_{6}$.

Fig. 9. Variation of $1 / \chi_{\mathrm{m}}(\mathrm{Oe} * \mathrm{~mole} / \mathrm{emu})$ and $\mu_{\mathrm{eff}}$ (effective Bohr magnetons), respectively, with temperature for $\mathrm{La}_{2} \mathrm{Co}_{1+z}\left(\mathrm{Mg}_{\mathrm{x}} \mathrm{Ti}_{1-\mathrm{x}}\right)_{1-z} \mathrm{O}_{6}$ with $(\mathrm{a}, \mathrm{b}) \mathrm{x}=0$, (c,d) $\mathrm{x}=0.25$, (e,f) $\mathrm{x}=0.5$, $(\mathrm{g}, \mathrm{h}) \mathrm{x}=0.75$.

Fig. 10. Observed effective magnetic moments $\mu_{\text {eff }}$ for $\operatorname{La}_{2} \mathrm{CoMg}_{x} \mathrm{Ti}_{1-x} \mathrm{O}_{6}(0 \leq x \leq 0.6)$. Expected moments for $\mathrm{HS} \mathrm{Co}^{2+}, \mathrm{Co}^{3+}$ and $\mathrm{Co}^{4+}$ in HS, IS, and LS states are indicated.

Fig. 11 (a) Ti- $K$ and (b) Co- $K$ edge spectra of the selected samples in the $\mathrm{La}_{2} \mathrm{Co}_{1+\mathrm{z}}\left(\mathrm{Ti}_{1-\mathrm{x}} \mathrm{Mg}_{\mathrm{x}}\right)_{1-}$ ${ }_{z} \mathrm{O}_{6}$ series. $x$ refers to $\mathrm{La}_{2} \mathrm{Co}\left(\mathrm{Ti}_{1-\mathrm{x}} \mathrm{Mg}_{\mathrm{x}}\right) \mathrm{O}_{6}$ and $\mathrm{z}$ refers to $\mathrm{La}_{2} \mathrm{Co}_{1+\mathrm{z}}\left(\mathrm{Ti}_{0.5} \mathrm{Mg}_{0.5}\right)_{1-\mathrm{z}} \mathrm{O}_{6}$ sub-series. Insets: Energy position of the $\operatorname{Co} 4 p$ feature as a function of formal cobalt valence demonstrating the chemical shift. Energy positions were defined by fitting a tip of function of form $\left[\operatorname{Gaussian}\left(\mathrm{A}_{\mathrm{G}}, \mathrm{E}_{\mathrm{o}}, \mathrm{W}\right)+\operatorname{Gaussian} \operatorname{step}\left(\mathrm{A}_{\mathrm{S}}=1.0, \mathrm{E}_{\mathrm{o}}, \mathrm{W}\right)\right]\left(\mathrm{A}=\operatorname{amplitude}, \mathrm{E}_{\mathrm{o}}=\right.$ energy position and $\mathrm{W}=$ width). Different samples in the $\mathrm{La}_{2} \mathrm{Co}_{1+\mathrm{z}}\left(\mathrm{Ti}_{0.5} \mathrm{Mg}_{0.5}\right)_{1-\mathrm{z}} \mathrm{O}_{6}$ sub-series, for which the formal oxidation state of $\mathrm{Co}$ is $3+$, are highlighted with colors.

Fig. $12 \mathrm{Ti}-L_{2,3}$ spectra of the selected samples in the $\mathrm{La}_{2} \mathrm{Co}_{1+\mathrm{z}}\left(\mathrm{Ti}_{1-\mathrm{x}} \mathrm{Mg}_{\mathrm{x}}\right)_{1-\mathrm{z}} \mathrm{O}_{6}$ series. Extreme values of the peak-splitting are high-lighted. $x$ refers to $\mathrm{La}_{2} \mathrm{Co}\left(\mathrm{Ti}_{1-\mathrm{x}} \mathrm{Mg}_{\mathrm{x}}\right) \mathrm{O}_{6}$ and $\mathrm{z}$ refers to $\mathrm{La}_{2} \mathrm{Co}_{1+\mathrm{z}}\left(\mathrm{Ti}_{0.5} \mathrm{Mg}_{0.5}\right)_{1-\mathrm{z}} \mathrm{O}_{6}$ sub-series.

Fig.13 (a) Co- $L_{2,3}$ spectra of the selected samples in the $\mathrm{La}_{2} \mathrm{Co}_{1+\mathrm{z}}\left(\mathrm{Ti}_{1-\mathrm{x}} \mathrm{Mg}_{\mathrm{x}}\right)_{1-\mathrm{z}} \mathrm{O}_{6}$ series. $\mathrm{x}$ refers to $\mathrm{La}_{2} \mathrm{Co}\left(\mathrm{Ti}_{1-\mathrm{x}} \mathrm{Mg}_{\mathrm{x}}\right) \mathrm{O}_{6}$ and $\mathrm{z}$ refers to $\mathrm{La}_{2} \mathrm{Co}_{1+\mathrm{z}}\left(\mathrm{Ti}_{0.5} \mathrm{Mg}_{0.5}\right)_{1-\mathrm{z}} \mathrm{O}_{6}$ sub-series. (b) Shifts of the centers of gravities of the Co- $L_{2}$ and $-L_{3}$ branches and (c) branching ratio as a function of formal oxidation state of $\mathrm{Co}$. Different samples in the $\mathrm{La}_{2} \mathrm{Co}_{1+\mathrm{z}}\left(\mathrm{Ti}_{0.5} \mathrm{Mg}_{0.5}\right)_{1-\mathrm{z}} \mathrm{O}_{6}$ sub-series, for which the formal oxidation state of $\mathrm{Co}$ is $3+$, are highlighted with colors.

Fig. 14 (a) $\mathrm{O}-K$ spectra of the selected samples in the $\mathrm{La}_{2} \mathrm{Co}_{1+\mathrm{z}}\left(\mathrm{Ti}_{1-\mathrm{x}} \mathrm{Mg}_{\mathrm{x}}\right)_{1-\mathrm{z}} \mathrm{O}_{6}$ system. $\mathrm{x}$ refers to $\mathrm{La}_{2} \mathrm{Co}\left(\mathrm{Ti}_{1-\mathrm{x}} \mathrm{Mg}_{\mathrm{x}}\right) \mathrm{O}_{6}$ and $\mathrm{z}$ refers to $\mathrm{LaCo}_{1+\mathrm{z}}\left(\mathrm{Ti}_{0.5} \mathrm{Mg}_{0.5}\right)_{1-\mathrm{z}} \mathrm{O}_{6}$ sub-series. (Division into hybrid regions, see e.g. [52] ) (b) Peak-fitting scheme for the $\mathrm{Co} / \mathrm{Ti} 3 d-\mathrm{O} 2 p$ hybrid structure: Two functions $f_{1}$ and $f_{2}$ of $\left[\left(\operatorname{Gaussian}\left(\mathrm{A}_{\mathrm{G}}, \mathrm{E}_{\mathrm{o}}, \mathrm{W}\right)+\tanh \left(\mathrm{A}_{\mathrm{T}}, \mathrm{E}_{\mathrm{o}}, \mathrm{W} / 2\right)\right)\right]$ form were fitted. $\mathrm{A}_{\mathrm{G}}$ and 
$\mathrm{A}_{\mathrm{T}}$ parameters were iterated so that $\mathrm{A}_{\mathrm{G}}\left(f_{1}\right) / \mathrm{A}_{\mathrm{T}}\left(f_{1}\right)=\mathrm{A}_{\mathrm{G}}\left(f_{1}\right) / \mathrm{A}_{\mathrm{T}}\left(f_{1}\right)$. The energy positions of the $\mathrm{E}$ and $\mathrm{F}$ features, that remained unchanged in all samples without any forced convergence, are also indicated. (c) $(E /(E+F)) /(1+z)$ as a function of the formal oxidation state of Co. Different samples in the $\mathrm{LaCo}_{1+\mathrm{z}}\left(\mathrm{Ti}_{0.5} \mathrm{Mg}_{0.5}\right)_{1-\mathrm{z}} \mathrm{O}_{6}$ sub-series, for which the formal oxidation state of $\mathrm{Co}$ is $3+$, are highlighted with colours. 


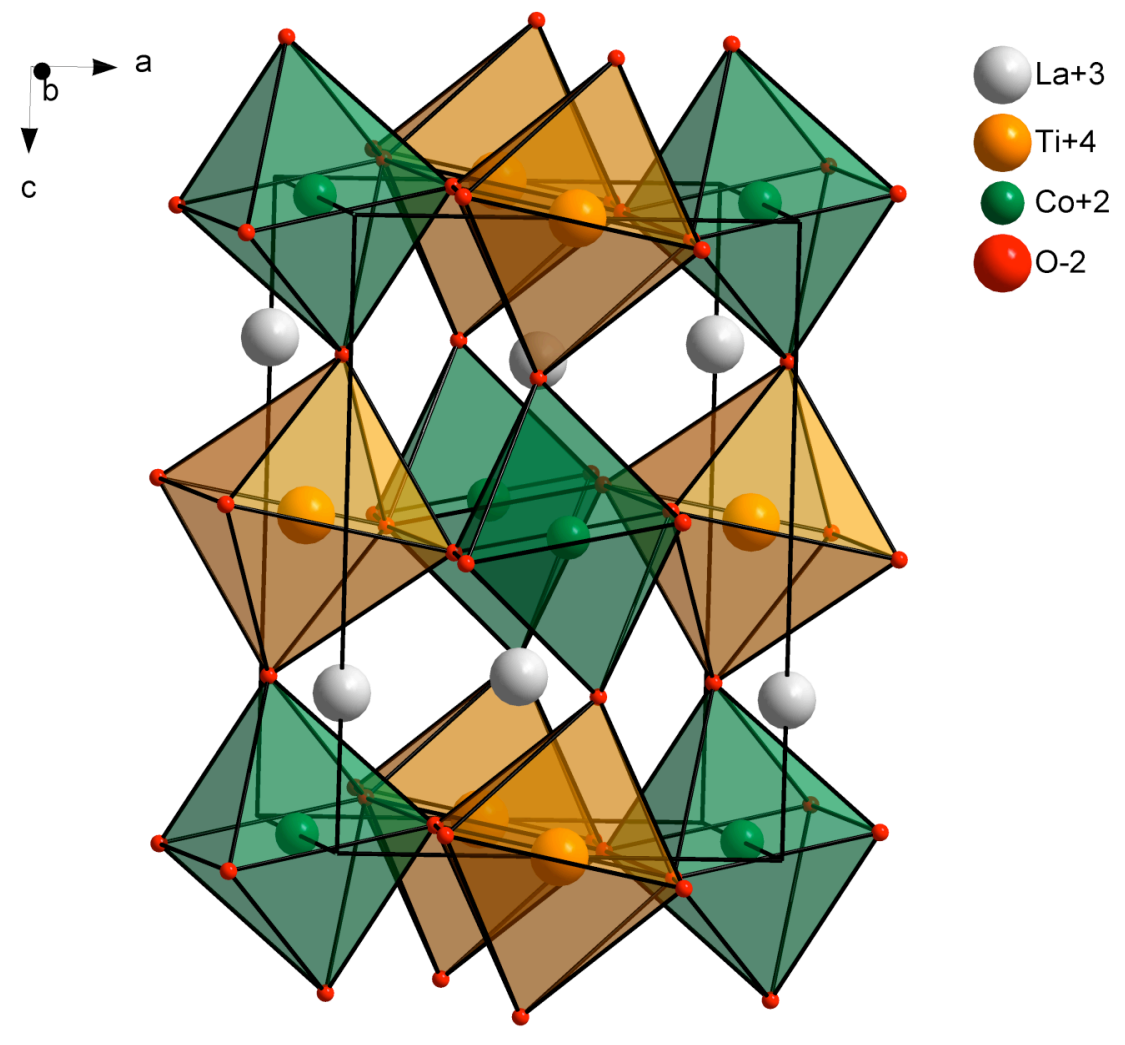

Fig. 1. Illustration of the double perovskite $P 2_{1} / n$ symmetry structure of $\mathrm{La}_{2} \mathrm{CoTiO}_{6}$ with alternating $\mathrm{Co}^{2+}$ (green) and $\mathrm{Ti}^{4+}$ (orange) octahedra. 


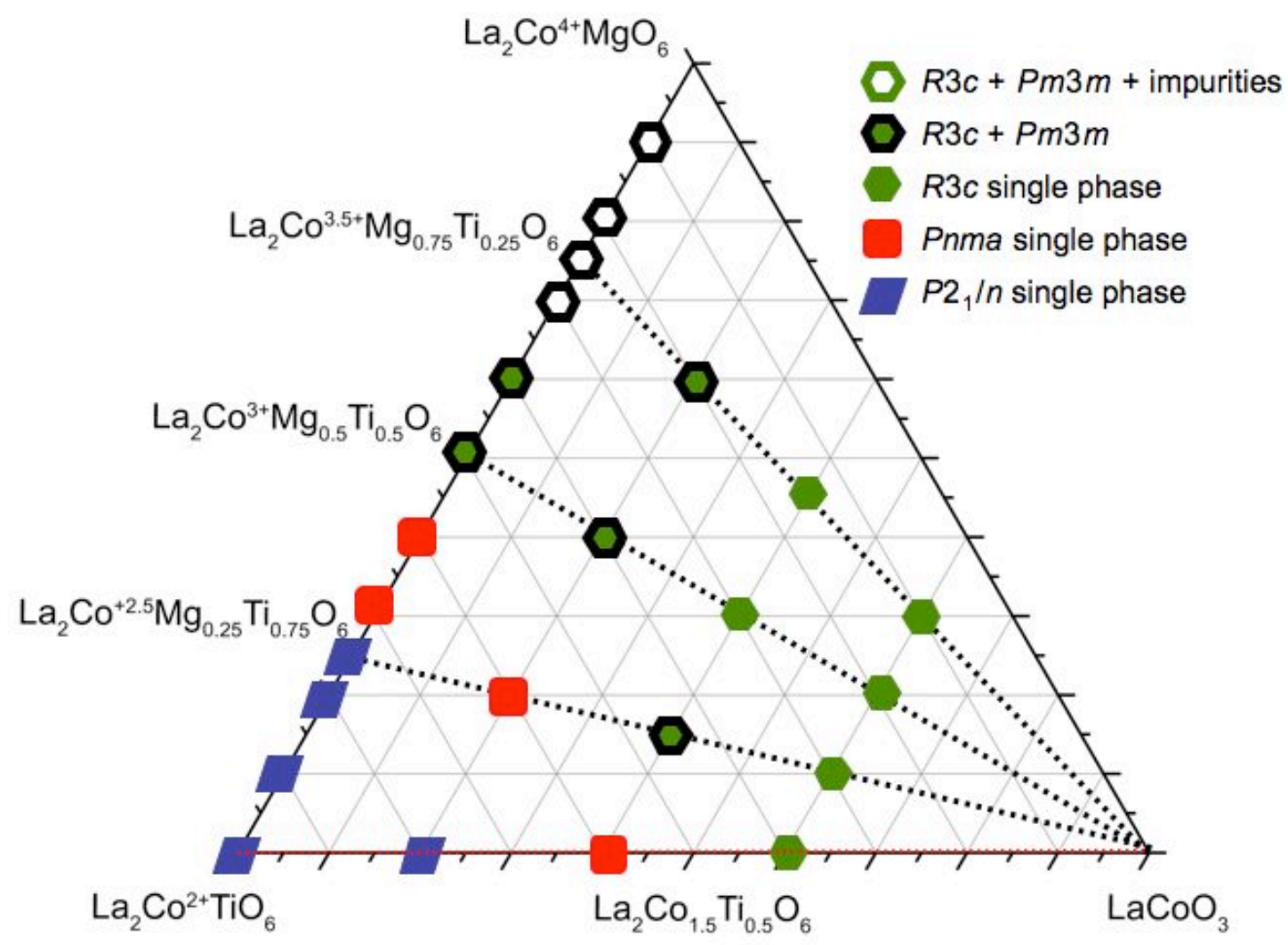

Fig. 2. Compositional triangle with corners $\mathrm{La}_{2} \mathrm{CoTiO}_{6}-\mathrm{La}_{2} \mathrm{CoMgO}_{6}-\mathrm{LaCoO}_{3}$, showing prepared compositions and symmetries of the observed perovskite-type structures. 
Fig. 3. Symmetry distinguishing SAED patterns for: (a) Monoclinic $P 2_{1} / n \mathrm{La}_{2} \mathrm{CoMg}_{0.2} \mathrm{Ti}_{0.8} \mathrm{O}_{6}$ along $[100]_{\text {mon }}=[110]_{\mathrm{p}}$, with no systematic absences revealed due to the presence of weak superstructure reflections (some are marked with arrows). (The expected reflection condition $00 l ; l=2 n$ is not fulfilled due to double diffraction) (b) Orthorhombic Pbnm $\mathrm{La}_{2} \mathrm{CoMg}_{0.3} \mathrm{Ti}_{0.7} \mathrm{O}_{6}$ along $[100]_{\text {ort }}=[110]_{\mathrm{p}}$, with reflection conditions $0 k l ; k=2 n$. The doubling of the perovskite caxis $\left(c=2 c_{p}\right)$ gives rise to weak superstructure reflections (some are marked with arrows). (The reflection condition $00 l ; l=2 n$ is not fulfilled due to double diffraction) (c) rhombohedral, $R \overline{3} c \quad \mathrm{La}_{2} \mathrm{CoMg}_{0.4} \mathrm{Ti}_{0.6} \mathrm{O}_{6}$ along $[110]_{\text {rho }}=[110]_{\mathrm{p}}$, where no superstructure reflections are present. The contrast has been enhanced in order to easier visualise the weaker spots. 


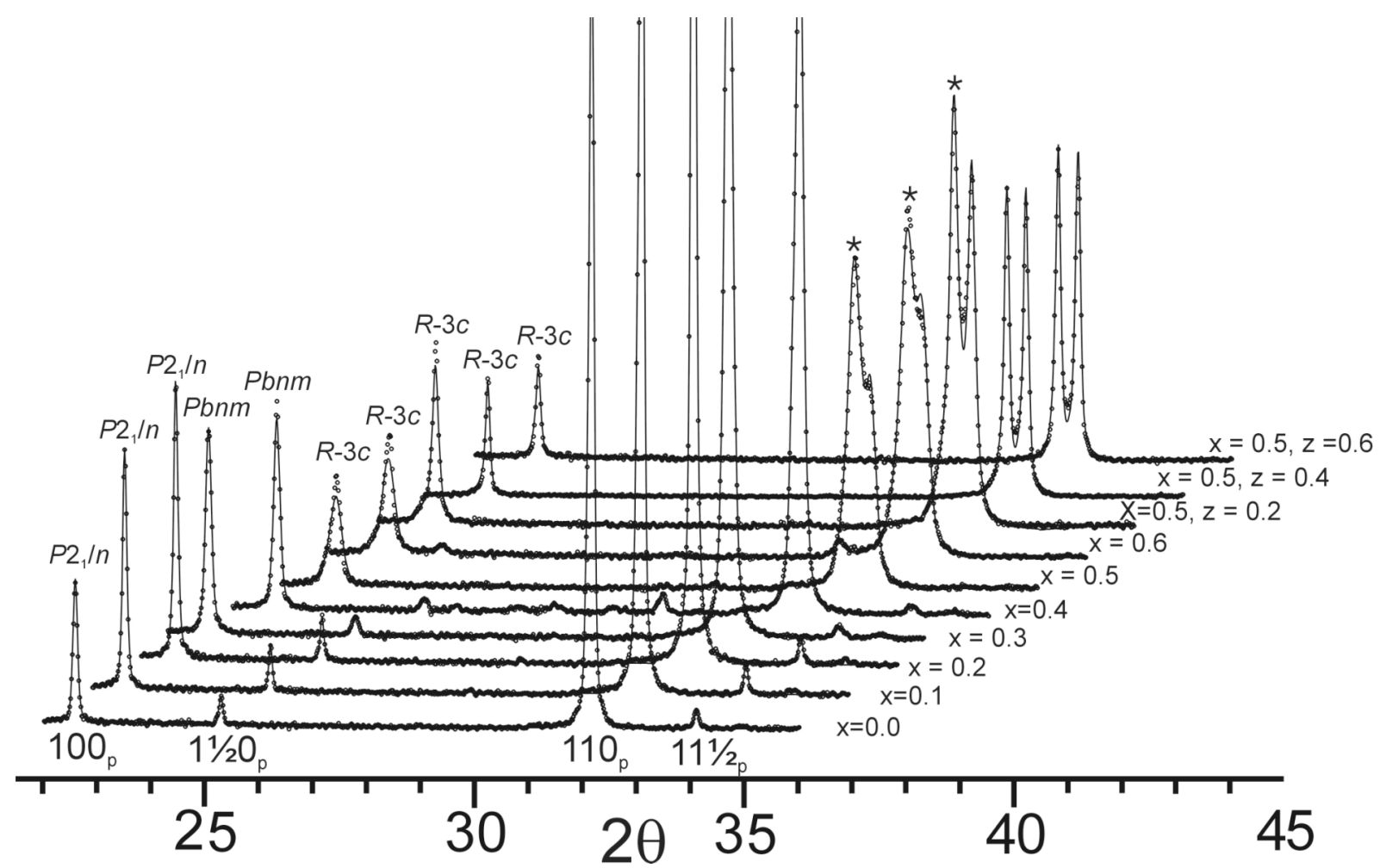

Fig. 4. Selected observed (small circles) and calculated (full lines) XRPD patterns for compositions along the lines $\mathrm{La}_{2} \mathrm{Co}\left(\mathrm{Mg}_{x} \mathrm{Ti}_{1-x}\right) \mathrm{O}_{6}$ and $\mathrm{La}_{2} \mathrm{Co}_{1+z}\left(\mathrm{Mg}_{0.5} \mathrm{Ti}_{0.5}\right)_{1-z} \mathrm{O}_{6}$. Positions of reflections from the cubic $\operatorname{Pm} \overline{3} m$ phases are indicated by asterisks. 

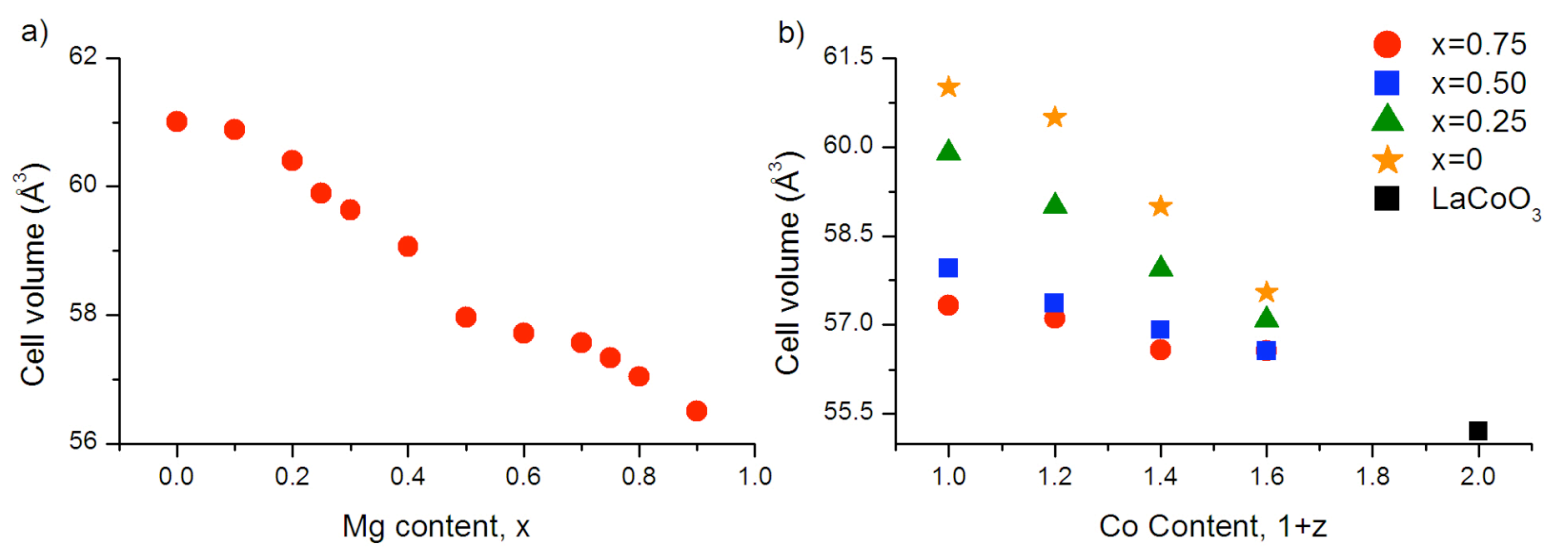

Fig. 5. Perovskite sub-cell volume (a) as a function of $x$ in $\mathrm{La}_{2} \mathrm{Co}\left(\mathrm{Mg}_{x} \mathrm{Ti}_{1-x}\right) \mathrm{O}_{6}$ and (b) versus $z$ in $\mathrm{La}_{2} \mathrm{Co}_{1+z}\left(\mathrm{Mg}_{x} \mathrm{Ti}_{1-x}\right)_{1-z} \mathrm{O}_{6}$ for $\mathrm{x}=0.0,0.25,0.50,0.75$.

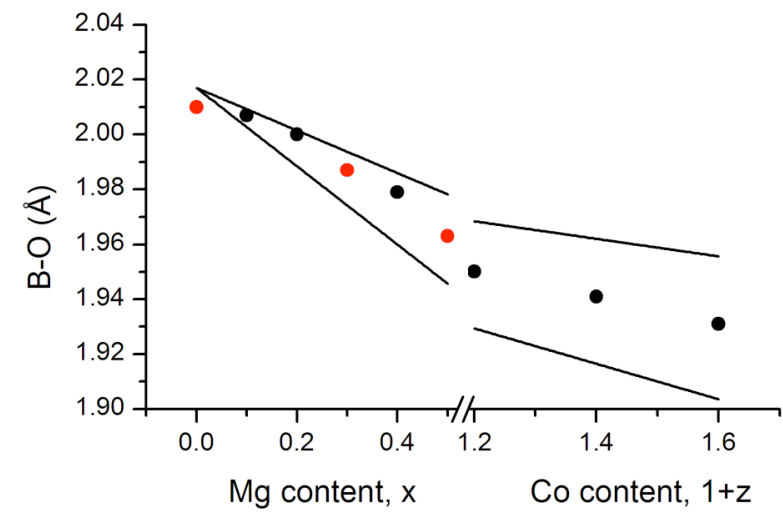

Fig. 6. Observed compositional dependence of the variation of average octahedral B - O interatomic distances as a function of $x$ in $\mathrm{La}_{2} \mathrm{Co}\left(\mathrm{Mg}_{x} \mathrm{Ti}_{1-x}\right) \mathrm{O}_{6}$ and $z$ in $\mathrm{La}_{2} \mathrm{Co}_{1+z}\left(\mathrm{Mg}_{0.5} \mathrm{Ti}_{0.5}\right)_{1-z} \mathrm{O}_{6}$. The values for $x=0.0,0.3$ and 0.5 are from NPD data. The lines are indicated for theoretical estimates of B-O variation for HS (upper line) LS (lower line) using the Shannon ionic radii ${ }^{22}$ and an estimated oxygen radii of $1.342 \AA$. 

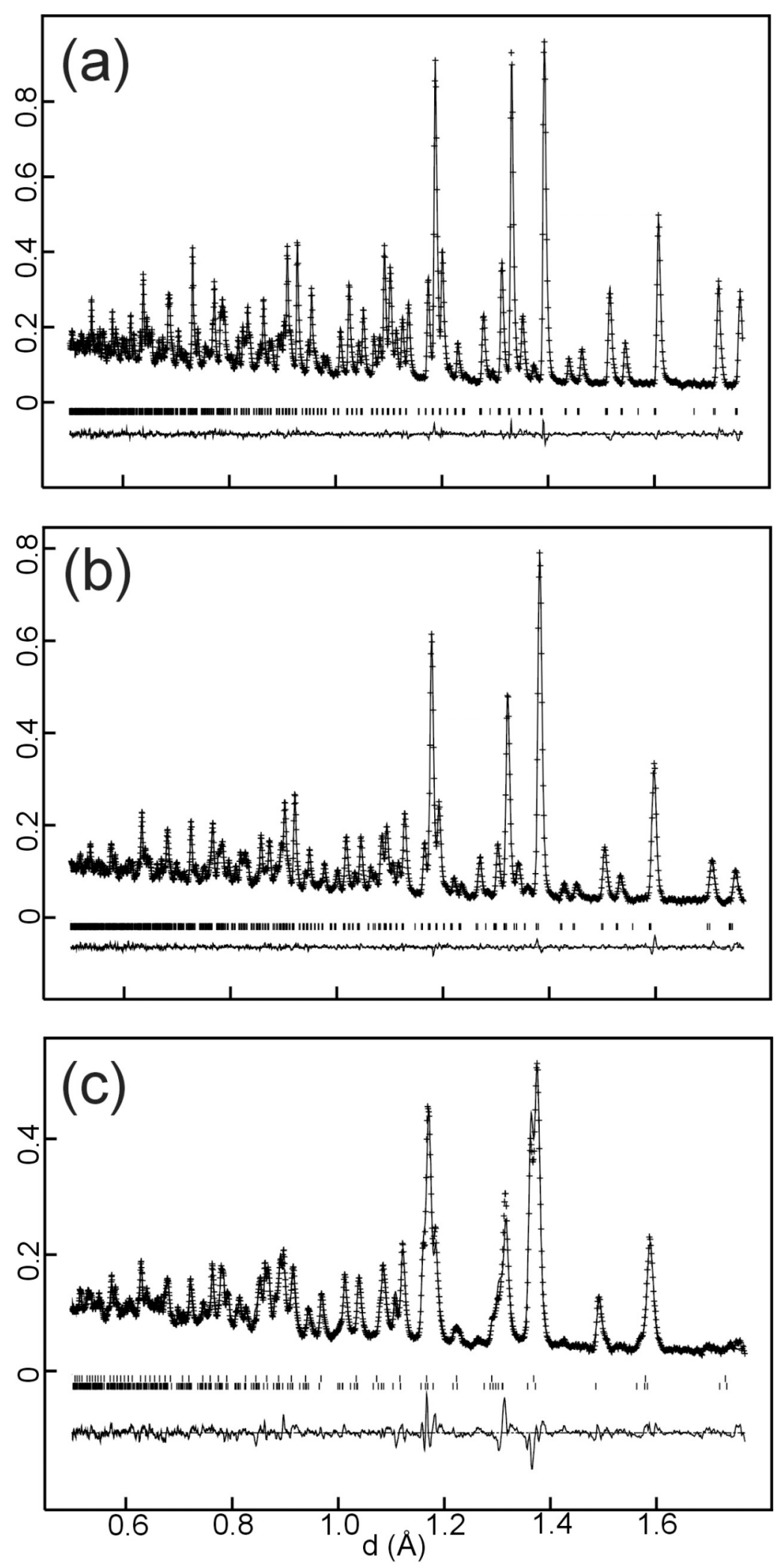

Fig. 7. Observed (crosses), calculated (line) and difference (bottom) time-of-flight NPD patterns for (a) monoclinic $P 2_{1} / n \mathrm{La}_{2} \mathrm{CoTiO}_{6}$, (b) orthorhombic Pbnm $\mathrm{La}_{2} \mathrm{Co}\left(\mathrm{Mg}_{0.3} \mathrm{Ti}_{0.7}\right)$, (c) rhombohedral $R \overline{3} c+$ cubic $P m \overline{3} m \mathrm{La}_{2} \mathrm{Co}\left(\mathrm{Mg}_{0.5} \mathrm{Ti}_{0.5}\right) \mathrm{O}_{3}$. 

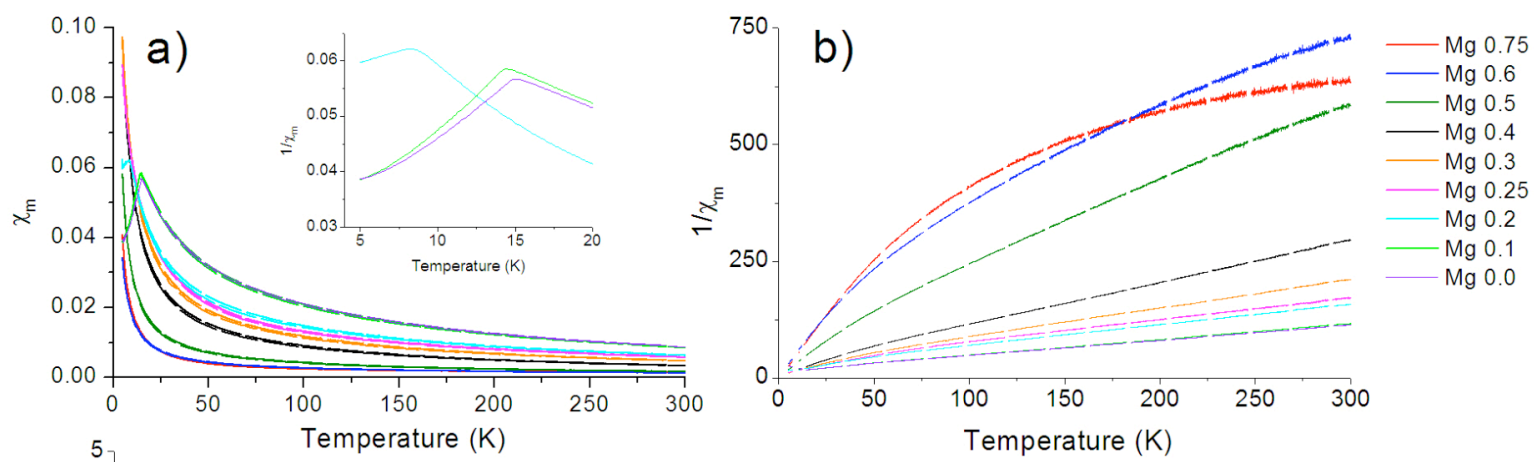

c)

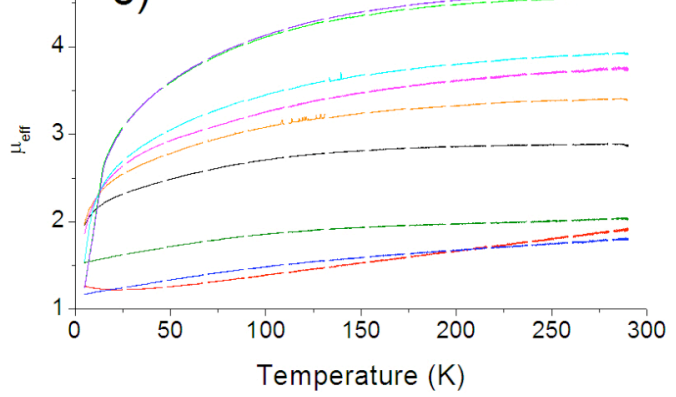

Fig. 8. Variation of (a) $\chi_{\mathrm{m}}(\mathrm{emu} / \mathrm{mole} * \mathrm{Oe})$, (b) $1 / \chi_{\mathrm{m}}(\mathrm{Oe} * \mathrm{~mole} / \mathrm{emu})$ and (c) $\mu_{\text {eff }}$ (effective Bohr magnetons) with temperature for the series $\mathrm{La}_{2} \mathrm{CoMg}_{\mathrm{x}} \mathrm{Ti}_{1-\mathrm{x}} \mathrm{O}_{6}$. 

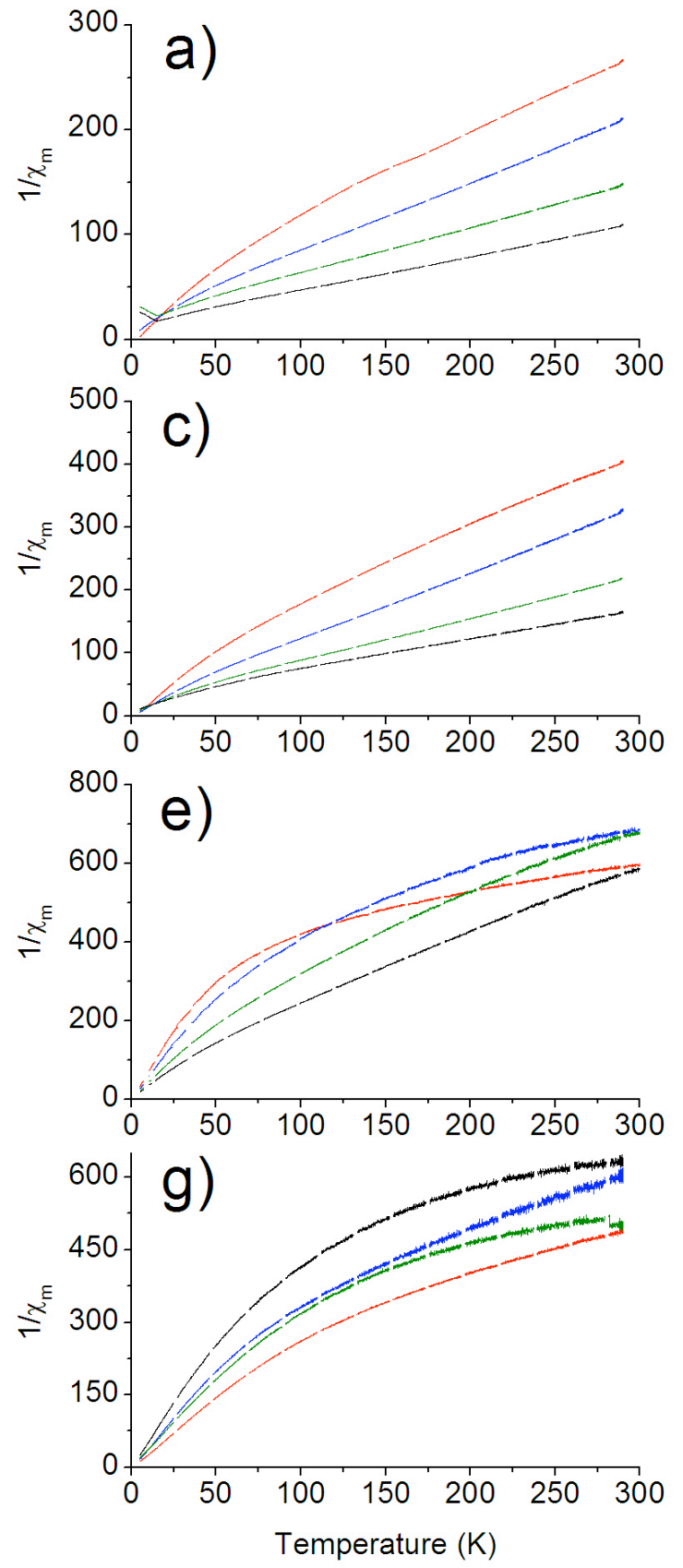
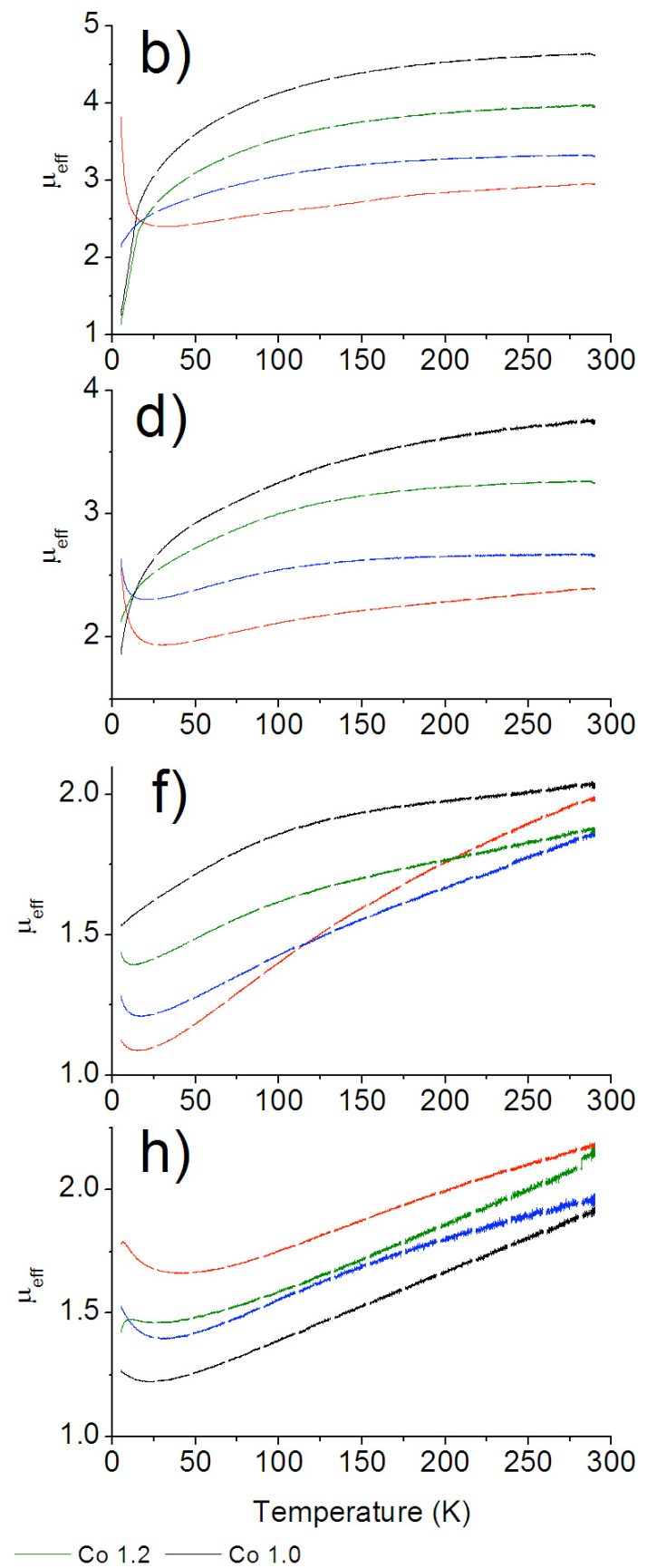

Fig. 9. Variation of $1 / \chi_{\mathrm{m}}(\mathrm{Oe} * \mathrm{~mole} / \mathrm{emu})$ and $\mu_{\mathrm{eff}}$ (effective Bohr magnetons)), respectively, with temperature for $\mathrm{La}_{2} \mathrm{Co}_{1+z}\left(\mathrm{Mg}_{\mathrm{x}} \mathrm{Ti}_{1-\mathrm{x}}\right)_{1-z} \mathrm{O}_{6}$ with $(\mathrm{a}, \mathrm{b}) \mathrm{x}=0$, (c,d) $\mathrm{x}=0.25$, (e,f) $\mathrm{x}=0.5$, $(\mathrm{g}, \mathrm{h}) \mathrm{x}=0.75$. 


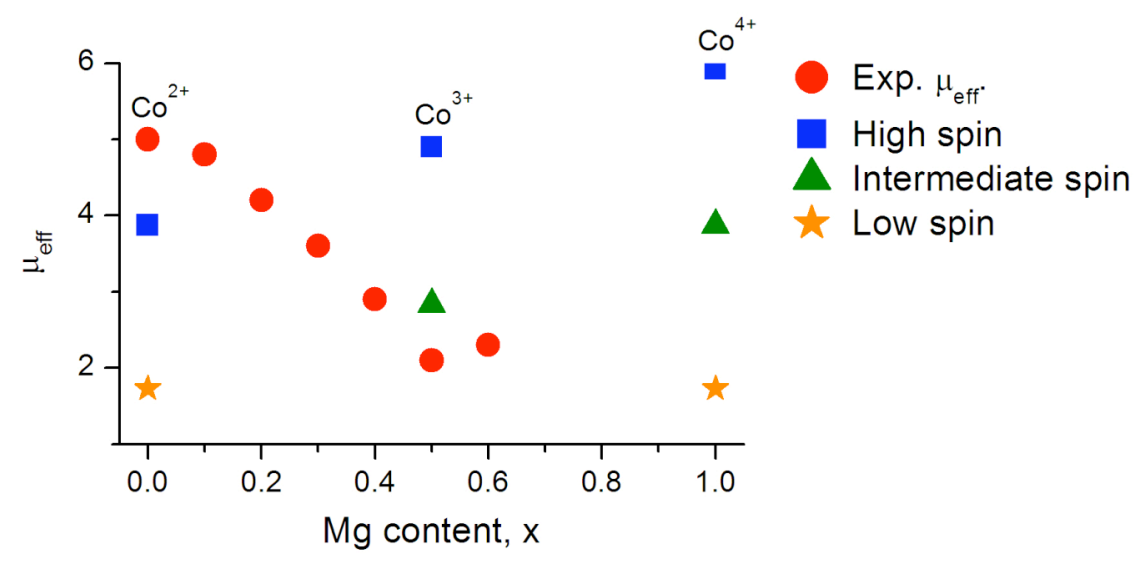

Fig. 10. Observed effective magnetic moments $\mu_{\text {eff }}$ for $\operatorname{La}_{2} \mathrm{CoMg}_{x} \mathrm{Ti}_{1-x} \mathrm{O}_{6}(0 \leq x \leq 0.6)$.

Expected moments for $\mathrm{HS} \mathrm{Co}^{2+}, \mathrm{Co}^{3+}$ and $\mathrm{Co}^{4+}$ in HS, IS, and LS states are indicated. 

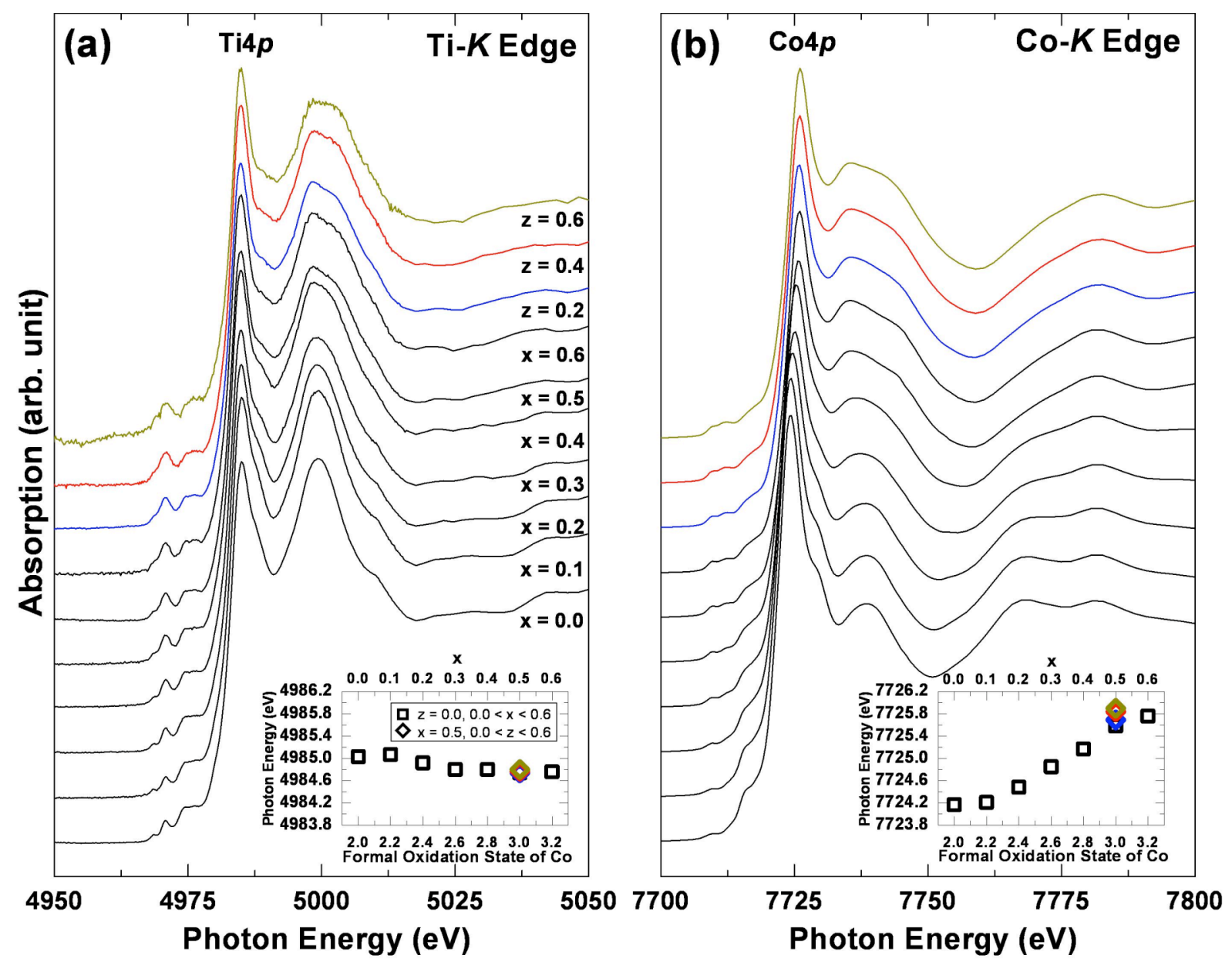

Fig. 11 (a) Ti- $K$ and (b) Co- $K$ edge spectra of the selected samples in the $\mathrm{La}_{2} \mathrm{Co}_{1+z}\left(\mathrm{Ti}_{1-\mathrm{x}} \mathrm{Mg}_{\mathrm{x}}\right)_{1-}$ ${ }_{z} \mathrm{O}_{6}$ series. $x$ refers to $\mathrm{La}_{2} \mathrm{Co}\left(\mathrm{Ti}_{1-\mathrm{x}} \mathrm{Mg}_{\mathrm{x}}\right) \mathrm{O}_{6}$ and $\mathrm{z}$ refers to $\mathrm{La}_{2} \mathrm{Co}_{1+\mathrm{z}}\left(\mathrm{Ti}_{0.5} \mathrm{Mg}_{0.5}\right)_{1-\mathrm{z}} \mathrm{O}_{6}$ sub-series. Insets: Energy position of the $\operatorname{Co} 4 p$ feature as a function of formal cobalt valence demonstrating the chemical shift. Energy positions were defined by fitting a tip of function of form $\left[\right.$ Gaussian $\left.\left(\mathrm{A}_{\mathrm{G}}, \mathrm{E}_{\mathrm{o}}, \mathrm{W}\right)+\operatorname{Gaussian} \operatorname{step}\left(\mathrm{A}_{\mathrm{S}}=1.0, \mathrm{E}_{\mathrm{o}}, \mathrm{W}\right)\right]\left(\mathrm{A}=\right.$ amplitude, $\mathrm{E}_{\mathrm{o}}=$ energy position and $\mathrm{W}=$ width). Different samples in the $\mathrm{La}_{2} \mathrm{Co}_{1+\mathrm{z}}\left(\mathrm{Ti}_{0.5} \mathrm{Mg}_{0.5}\right)_{1-\mathrm{z}} \mathrm{O}_{6}$ sub-series, for which the formal oxidation state of $\mathrm{Co}$ is $3+$, are highlighted with colors. 


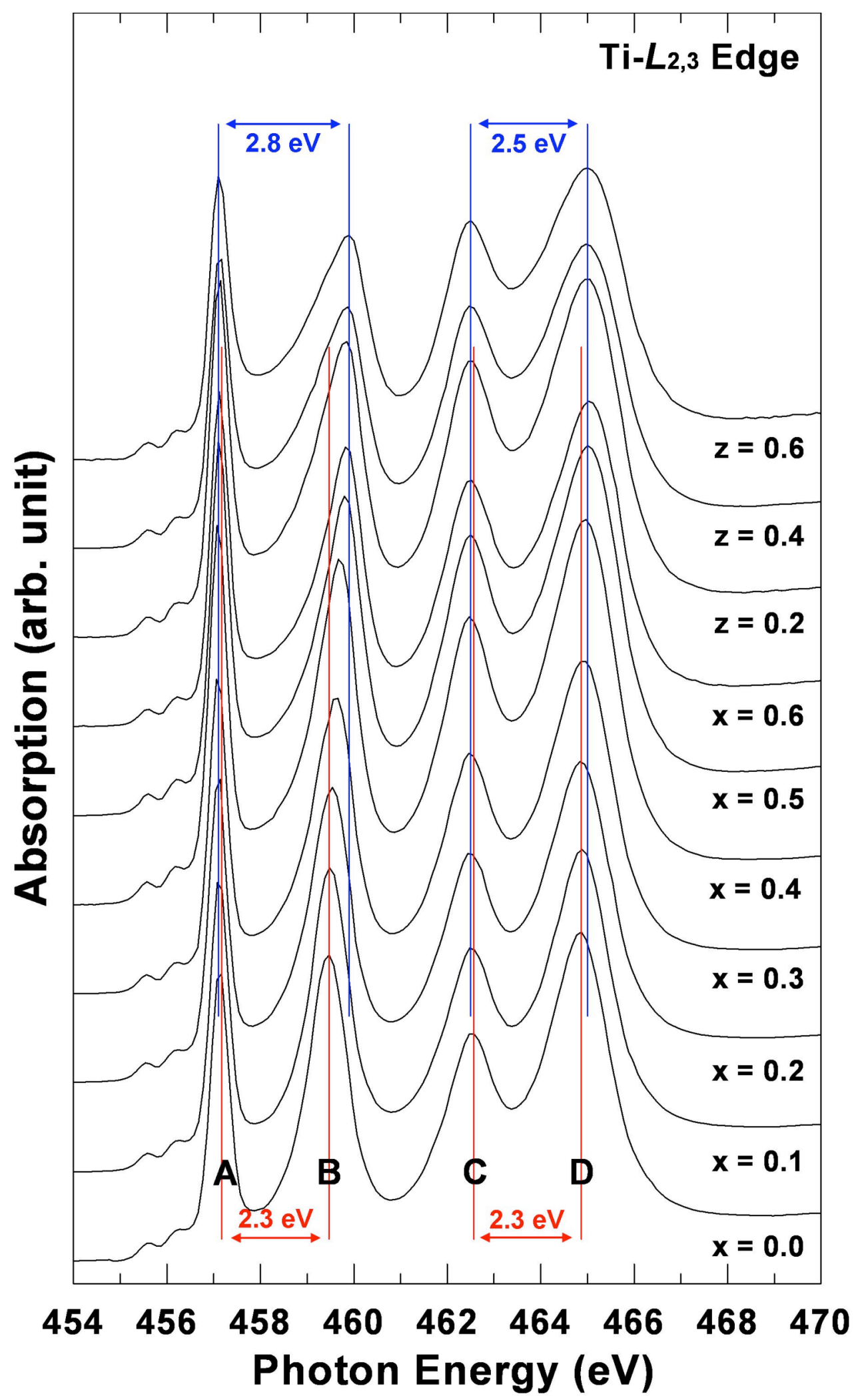

Fig. $12 \mathrm{Ti}-L_{2,3}$ spectra of the selected samples in the $\mathrm{La}_{2} \mathrm{Co}_{1+z}\left(\mathrm{Ti}_{1-\mathrm{x}} \mathrm{Mg}_{\mathrm{x}}\right)_{1-\mathrm{z}} \mathrm{O}_{6}$ series. Extreme values of the peak-splitting are high-lighted. $x$ refers to $\mathrm{La}_{2} \mathrm{Co}\left(\mathrm{Ti}_{1-\mathrm{x}} \mathrm{Mg}_{\mathrm{x}}\right) \mathrm{O}_{6}$ and $\mathrm{z}$ refers to $\mathrm{La}_{2} \mathrm{Co}_{1+\mathrm{z}}\left(\mathrm{Ti}_{0.5} \mathrm{Mg}_{0.5}\right)_{1-\mathrm{z}} \mathrm{O}_{6}$ sub-series. 

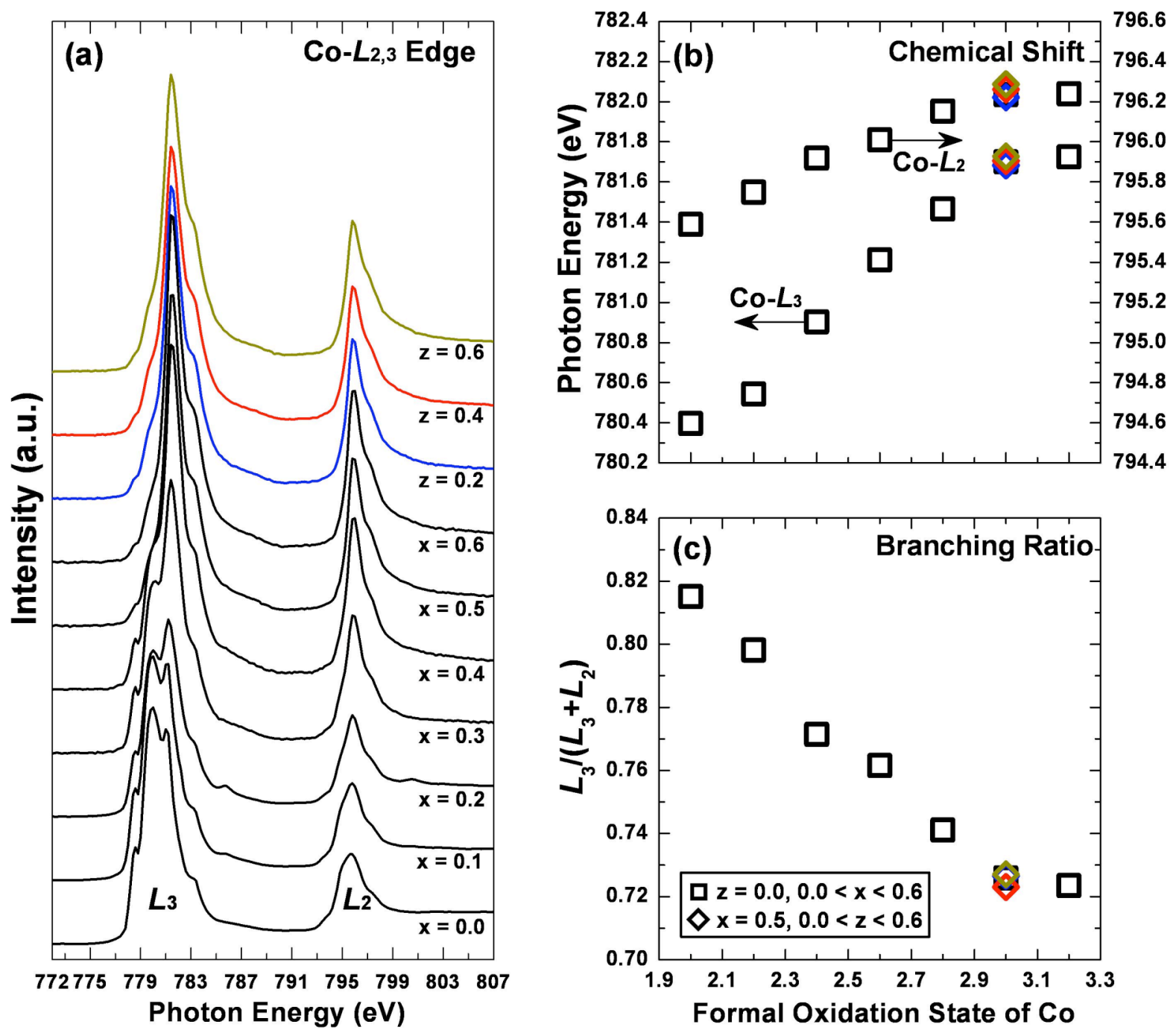

Fig.13 (a) Co- $L_{2,3}$ spectra of the selected samples in the $\mathrm{La}_{2} \mathrm{Co}_{1+\mathrm{z}}\left(\mathrm{Ti}_{1-\mathrm{x}} \mathrm{Mg}_{\mathrm{x}}\right)_{1-\mathrm{z}} \mathrm{O}_{6}$ series. $\mathrm{x}$ refers to $\mathrm{La}_{2} \mathrm{Co}\left(\mathrm{Ti}_{1-\mathrm{x}} \mathrm{Mg}_{\mathrm{x}}\right) \mathrm{O}_{6}$ and $\mathrm{z}$ refers to $\mathrm{La}_{2} \mathrm{Co}_{1+\mathrm{z}}\left(\mathrm{Ti}_{0.5} \mathrm{Mg}_{0.5}\right)_{1-\mathrm{z}} \mathrm{O}_{6}$ sub-series. (b) Shifts of the centers of gravities of the Co- $L_{2}$ and $-L_{3}$ branches and (c) branching ratio as a function of formal oxidation state of Co. Different samples in the $\mathrm{La}_{2} \mathrm{Co}_{1+\mathrm{z}}\left(\mathrm{Ti}_{0.5} \mathrm{Mg}_{0.5}\right)_{1-\mathrm{z}} \mathrm{O}_{6}$ sub-series, for which the formal oxidation state of $\mathrm{Co}$ is $3+$, are highlighted with colors. 

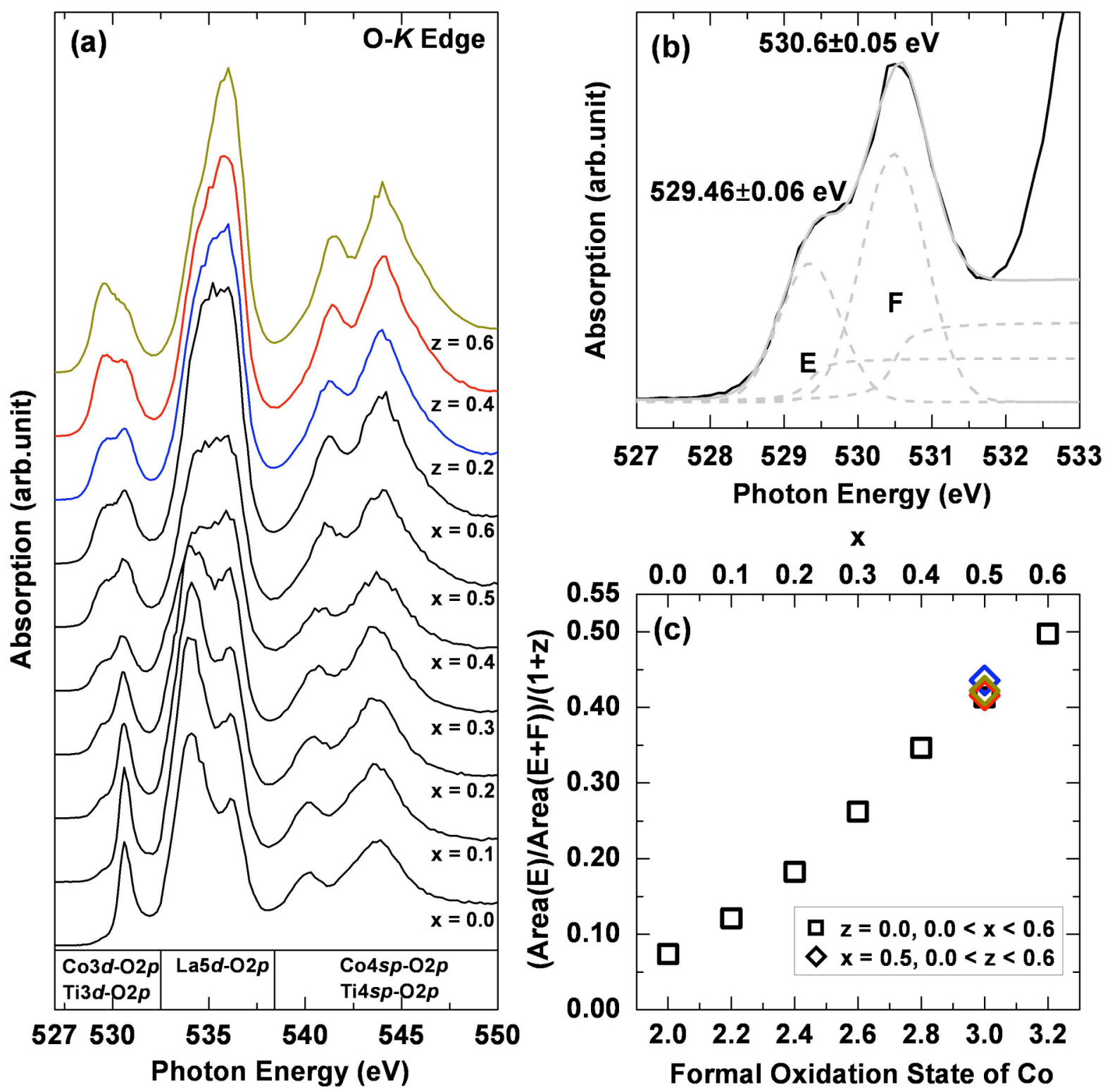

Fig. 14 (a) $O-K$ spectra of the selected samples in the $\mathrm{La}_{2} \mathrm{Co}_{1+z}\left(\mathrm{Ti}_{1-\mathrm{x}} \mathrm{Mg}_{\mathrm{x}}\right)_{1-\mathrm{z}} \mathrm{O}_{6}$ system. $\mathrm{x}$ refers to $\mathrm{La}_{2} \mathrm{Co}\left(\mathrm{Ti}_{1-\mathrm{x}} \mathrm{Mg}_{\mathrm{x}}\right) \mathrm{O}_{6}$ and $\mathrm{z}$ refers to $\mathrm{LaCo}_{1+\mathrm{z}}\left(\mathrm{Ti}_{0.5} \mathrm{Mg}_{0.5}\right)_{1-\mathrm{z}} \mathrm{O}_{6}$ sub-series. (Division into hybrid regions, see e.g. [51]) (b) Peak-fitting scheme for the $\mathrm{Co} / \mathrm{Ti} 3 d-\mathrm{O} 2 p$ hybrid structure: Two functions $f_{1}$ and $f_{2}$ of $\left[\left(\operatorname{Gaussian}\left(\mathrm{A}_{\mathrm{G}}, \mathrm{E}_{\mathrm{o}}, \mathrm{W}\right)+\tanh \left(\mathrm{A}_{\mathrm{T}}, \mathrm{E}_{\mathrm{o}}, \mathrm{W} / 2\right)\right)\right]$ form were fitted. $\mathrm{A}_{\mathrm{G}}$ and $\mathrm{A}_{\mathrm{T}}$ parameters were iterated so that $\mathrm{A}_{\mathrm{G}}\left(f_{1}\right) / \mathrm{A}_{\mathrm{T}}\left(f_{1}\right)=\mathrm{A}_{\mathrm{G}}\left(f_{1}\right) / \mathrm{A}_{\mathrm{T}}\left(f_{1}\right)$. The energy positions of the $\mathrm{E}$ and $\mathrm{F}$ features, that remained unchanged in all samples without any forced convergence, are also indicated. (c) $(\mathrm{E} /(\mathrm{E}+\mathrm{F})) /(1+\mathrm{z})$ as a function of the formal oxidation state of Co. Different samples in the $\mathrm{LaCo}_{1+\mathrm{z}}\left(\mathrm{Ti}_{0.5} \mathrm{Mg}_{0.5}\right)_{1-\mathrm{z}} \mathrm{O}_{6}$ sub-series, for which the formal oxidation state of $\mathrm{Co}$ is $3+$, are highlighted with colours. 